\title{
Visão de Mundo: ler, escrever e compreender as entrelinhas do saber
}

Recebido em 15.12.2015. Aprovado em 20.01.2016 Avaliado pelo sistema double blind review

\author{
Vera Lúcia Ávila Torres Naliato \\ vtorres@sesisp.org.br \\ Centro Educacional SESI N. 030 - Caçapava - SP - Brasil
}

\begin{abstract}
Resumo
Cotejando os resultados do SARESP, de 2008 a 2014, verificamos que em Língua Portuguesa praticamente não houve evolução na média das proficiências, já que a evolução da escola no período foi de apenas 4,7 pontos. Analisamos as redações dos alunos e observamos a necessidade de um reforço no ensino e na avaliação acerca da leitura e da escrita. Boa parte dos estudantes se mostrou incapaz de escrever sem erros ortográficos, encadear um raciocínio com princípio, meio e fim, interpretar um texto ou perceber o sentido do que é dito na aula. Houve também problema na oralidade.
\end{abstract}

Diante do baixo nível de proficiência em Língua Portuguesa propusemos o presente projeto - "Visão de Mundo - Ler, escrever e compreender as entrelinhas do saber" -, que contempla ações de incentivo e promoção da leitura, concebendo 0 ato de ler como um ato de compreensão e interação do leitor com a realidade e com o mundo que o cerca. Tem como foco fazer da escola uma comunidade de leitores e escritores, favorecendo a formação de seres humanos competentes e capazes de lerem as entrelinhas. Através da literatura, busca-se ampliar o mundo imaginário e para chegar ao prazer do texto. Visa constituir um espaço interativo entre as diversas manifestações de sentido, como forma de desenvolver múltiplas linguagens como a literária, a cênica, a plástica visual e a audiovisual, de modo a estimular a prática de leitura de forma crítica e criativa.

Apresenta como objetivo estratégico aumentar o nível de compreensão dos alunos em Língua Portuguesa e Redação, estimular um processo de leitura permanente e melhorar a qualidade do ensino através de formação continuada em serviço e da ampliação do acervo de livros. Ao dominar a leitura, abre-se ao aluno a possibilidade de adquirir conhecimentos, alargar a visão de mundo, desenvolver raciocínio e participar ativamente da vida social.

Para a implementação do projeto haverá necessidade de um investimento no valor de $\mathrm{R} \$ 86.880,35$, solicitado através do Edital, com contrapartida da escola no valor de $\mathrm{R} \$ 18.626,36$.

Palavras-chaves: Plano de Empreendimento. Empreendedorismo e Educação. Reforço escolar. Leitura. 


\section{Caracterização da Escola}

O Centro Educacional SESI N..$^{\circ}$ 030, localizado em Caçapava Preto (SP), foi fundado em $1964 \mathrm{e}$ atende ao $1^{\circ}$ ao $9^{\circ}$ ano do Ensino Fundamental. A escola tem como missão "oferecer uma educação de excelência, contribuindo para a formação de cidadãos éticos, solidários, competentes e socialmente responsáveis. ", e a visão de "Ser referência estadual na área educacional até o ano de 2022, estando entre os dez melhores resultados do SARESP."

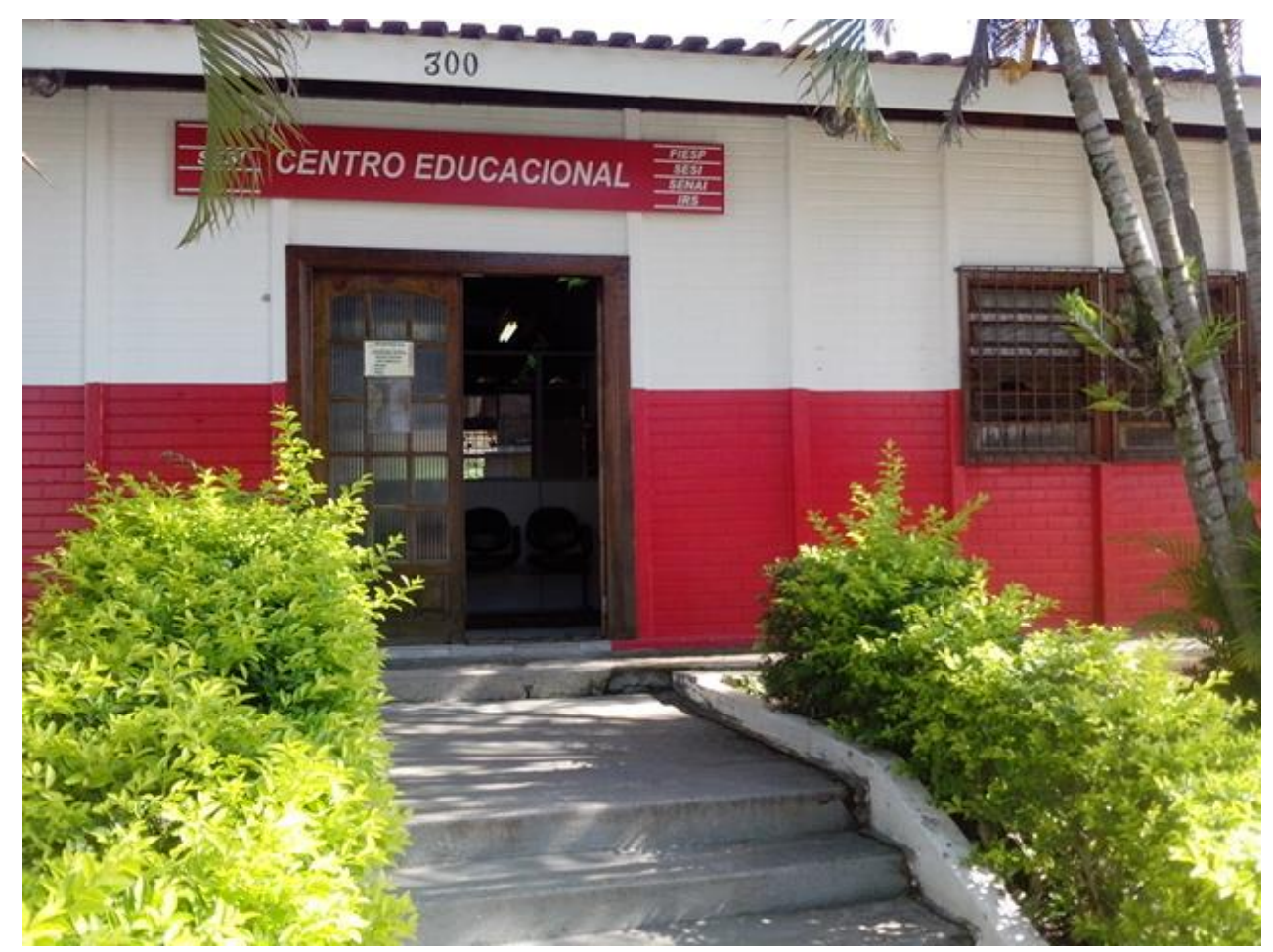

\section{Instalações}

O Centro Educacional SESI N. ${ }^{\circ} 030$ está instalado em um prédio horizontal, cedido pela Prefeitura Municipal de Caçapava. Sua estrutura física contempla uma quadra poliesportiva descoberta; um pátio interno, onde funciona o refeitório; seis salas de aula equipadas com televisores de LCD, aparelhos de DVD e projetores multimídia; um laboratório de ciência e tecnologia, equipado com dezessete computadores, impressoras, lousa digital, mesa de robótica e maletas Lego. Nesse laboratório o analista de suporte em informática desenvolve com os alunos a robótica educacional, através da metodologia Lego Zoom, que possibilita à equipe discente o desenvolvimento da criatividade, das relações interpessoais, do trabalho em equipe, da ética e da cidadania. O referido laboratório é também utilizado pelos professores no desenvolvimento de suas aulas, como mais um recurso para o trabalho de pesquisa junto à equipe discente.

A estrutura física do prédio compreende ainda uma sala para secretaria escolar; uma sala para direção; uma sala para coordenação pedagógica; uma sala para professores; uma sala para arquivo permanente; uma sala para guarda de materiais, onde se encontram as caixas estantes, contendo livros para leitura; uma cozinha; um sanitário feminino para funcionárias; um sanitário masculino para funcionários; seis sanitários femininos para as alunas e cinco sanitários masculinos para os alunos. Cabe ressaltar que há, em todos os ambientes, equipamentos adequados ao bom desenvolvimento dos trabalhos e o estado de conservação dos espaços, como também dos equipamentos, é satisfatório. 


\section{Breve histórico}

O quadro a seguir apresenta a relação dos acontecimentos mais relevantes para a evolução da escola, desde a fundação até hoje:

\begin{tabular}{|c|l|}
\hline \multicolumn{1}{|l|}{ Ano } & Acontecimentos relevantes \\
\hline 1964 & Fundação da escola \\
\hline 1997 & Mudança de prédio na mesma cidade \\
\hline 2003 & Passou a oferecer a Modalidade EJA - Educação a Distância \\
\hline 2010 & Implantação do Ensino Fundamental de 9 anos \\
\hline 2011 & $\begin{array}{l}\text { Projeto da unidade apresentado no Congresso Internacional de Educação - } \\
\text { ICSEl - Santiago/Chile }\end{array}$ \\
\hline
\end{tabular}

\section{Professores e funcionários}

A equipe é formada por quinze professores, distribuídos da seguinte forma:

\begin{tabular}{|l|c|}
\hline Disciplina / Área & Quant. de professores \\
\hline Professor de Educação Básica I - $1^{0}$ ao $5^{\circ}$ ano & 5 \\
\hline Professor de Educação Básica I - Auxiliar Docente & 1 \\
\hline Língua Portuguesa / Linguagens & 1 \\
\hline Educação Física / Linguagens & 1 \\
\hline Arte / Linguagens & 1 \\
\hline LEM - Inglês / Linguagens & 1 \\
\hline Matemática / Matemática & 1 \\
\hline Ciências da Natureza / Ciências da Natureza & 1 \\
\hline História e Geografia / Ciências Humanas & \\
\hline
\end{tabular}

Todos os professores são efetivos, licenciados e possuem habilitação específica na disciplinalárea em que atuam. Dentre eles, um possui mestrado e quatro são pós-graduados. Ingressaram na rede escolar SESI-SP através de processo seletivo, oriundos de outras redes de ensino, possuindo experiência no magistério.

Além disso, a escola conta com dez funcionários de apoio, sendo um diretor, um coordenador pedagógico, um secretário escolar, um assistente de serviços administrativos, dois inspetores de alunos, um analista de suporte em informática, dois auxiliares de serviços gerais e um auxiliar de cozinha.

\section{Perfil dos alunos}

Os alunos estão distribuídos por séries e turnos da seguinte maneira:

\begin{tabular}{|c|c|c|c|c|c|c|}
\hline \multirow{2}{*}{ Série/Ano } & \multirow{2}{*}{$\begin{array}{c}\text { Média de } \\
\text { idade }\end{array}$} & \multirow{2}{*}{$\begin{array}{c}\text { Total de } \\
\text { alunos }\end{array}$} & Manhã & \multicolumn{3}{|c|}{ Tarde } \\
\cline { 5 - 7 } & & $\mathbf{N}^{0}$ alunos & $\mathbf{N}^{0}$ turmas & $\mathbf{N}^{0}$ alunos & $\mathbf{N}^{0}$ turmas \\
\hline $1^{\circ}$ ano & 6,5 & 32 & - & - & 32 & 1 \\
\hline $2^{\circ}$ ano & 7,4 & 32 & - & - & 32 & 1 \\
\hline $3^{\circ}$ ano & 8,4 & 32 & - & - & 32 & 1 \\
\hline $4^{\circ}$ ano & 9,8 & 35 & - & - & 35 & 1 \\
\hline $5^{\circ}$ ano & 10,2 & 32 & - & - & 32 & 1 \\
\hline $6^{\circ}$ ano & 11,5 & 32 & 32 & 1 & - & - \\
\hline $7^{0}$ ano & 12,8 & 34 & 34 & 1 & - & - \\
\hline $8^{\circ}$ ano & 13,5 & 32 & 32 & 1 & - & - \\
\hline $9^{\circ}$ ano & 14,4 & 31 & 31 & 1 & - & - \\
\hline TOTAL $^{n n n n y y y}$ & - & 292 & 129 & 4 & 163 & 5 \\
\hline
\end{tabular}


Nos anos iniciais do Ensino Fundamental os estudantes demonstram grande comprometimento com os estudos, realizando as lições de casa e os trabalhos escolares. Apresentam excelente assiduidade e os responsáveis são presentes e participativos na dinâmica escolar, parceria que em muito favorece o processo de ensino e aprendizagem.

O comprometimento com as lições de casa, e o hábito de estudo, são reduzidos nos anos finais do Ensino Fundamental. Os professores são diversificados, como também suas sistematizações junto aos alunos. As famílias já não são tão presentes, residem no entorno da escola e isso possibilita que os estudantes se dirijam às aulas de bicicleta. Os estudantes que moram em bairros distantes utilizam 0 transporte escolar. Observa-se queda no rendimento e porcentagem elevada de alunos promovidos pelo conselho de classe.

Poucos são os estudantes que trabalham, como também são raros os casos de indisciplina. Não há problema de ordem comportamental que interfira significativamente no processo de ensino e aprendizagem, no entanto os estudantes parecem ainda não vislumbrar uma relação de diálogo efetiva entre professores e alunos no interior da escola, em que possam realmente interferir e opinar nas questões que afetam o seu destino no contexto escolar. Parecem atribuir maior valor à sala de aula do que a outras formas de participação, em que possam empreender na escola. Temos sensibilizado a equipe docente a fim de que a escola não continue a se organizar em torno da sala de aula, privilegiando os tempos rígidos e uma atuação burocrática, o que impede a participação efetiva do aluno.

\section{Características do entorno}

A cidade de Caçapava, na qual a escola está inserida, situa-se na região do Vale do Paraíba, que vivenciou o ciclo do café. Depois do café, no final do século XIX, seguiu-se um período de estagnação econômica na cidade. A recuperação só ocorreu em meados do século XX, com o cultivo do arroz e a introdução da pecuária de leite e acelerou-se na década de 1970, com a expansão das atividades industriais no município. Apesar de possuir um parque industrial razoável, as atividades de comércio e serviços em Caçapava podem ser consideradas como incipientes, tendo como justificativa para tal a proximidade com municípios como São José dos Campos e Taubaté, que são atrativos maiores à instalação de Shoppings Centers e Hipermercados, bem como maior variedade de serviços. Não há na cidade de Caçapava, por exemplo, uma livraria de grande porte, que apresente diversificação de títulos.

O Índice de Desenvolvimento Humano (IDHM) - Caçapava é 0,788, em 2010, o que situa esse município na faixa de Desenvolvimento Alto. A dimensão que mais contribui para o IDHM do município é Longevidade, com índice de 0,858, seguida de Educação, com índice de 0,755 e de Renda, com índice de 0,754. Caçapava é uma cidade tranquila, sem problemas de trânsito e com um sistema de transporte eficiente. Não há incidência de violência no bairro onde a escola se situa como também não há evidência de alunos que residem em bairros com índice significativo de violência.

O bairro onde a escola está inserida possui um posto de saúde, duas escolas municipais, duas creches municipais, uma quadra poliesportiva, dois parques infantis e um centro cultural, que oferece gratuitamente atividades culturais aos munícipes, com ênfase em festas populares, sendo a de São João um evento que mobiliza a cidade. Há parceria estabelecida entre Centro Educacional e Prefeitura Municipal. A quadra poliesportiva é utilizada pela comunidade nos finais de semana. Apesar de a clientela escolar, em sua maioria, apresentar características de classe média, se observa que aliada à baixa escolaridade dos responsáveis, a leitura e ou a compra de livros paradidáticos não ocorre com frequência fora do âmbito escolar. Momentos de lazer constituem-se em passeios aos Shoppings Centers dos municípios vizinhos, práticas esportivas, assistir televisão e visitas aos familiares. Com a atual crise econômica é observada elevada taxa de desemprego dos pais/responsáveis. 


\section{Identificação do Problema e da Oportunidade}

A identificação do problema partiu de um diagnóstico da Unidade Escolar. Para isso, foram observadas as principais avaliações externas, avaliações da equipe pedagógica, bem como relatórios internos de desempenho.

\section{IDEB}

Nos anos anteriores a 2011 a escola não apresenta nota no IDEB. Os alunos realizavam outro tipo de avaliação classificatória, o SIMEB, realizado internamente na Rede Escolar SESI-SP. Obtivemos o resultado do IDEB somente no ano de 2011.

\section{Resultado IDEB para $4^{\mathrm{a}}$ série $/ 5^{\circ}$ ano}

\begin{tabular}{|c|c|c|c|c|c|c|c|c|c|}
\hline ANO & 2005 & 2007 & 2009 & 2011 & 2013 & 2015 & 2017 & 2019 & 2021 \\
\hline Metas projetadas & - & - & - & 7,0 & - & - & - & - & - \\
\hline Ideb observado & - & - & - & 7,1 & - & - & - & - & - \\
\hline
\end{tabular}

Fonte: INEP

\section{Avaliação estadual}

O Centro Educacional participa do Sistema de Avaliação de Rendimento Escolar do Estado de São Paulo SARESP - que é a avaliação em larga escala da Secretaria Estadual de Educação e tem como finalidade avaliar competências e habilidades desenvolvidas pelos alunos no Ensino Fundamental e Médio. Essa avaliação é importante para avaliar os sistemas de ensino e nortear políticas públicas da área educacional no estado. Os resultados permitem à escola analisar o seu desempenho, no âmbito do sistema, para melhorar a qualidade da aprendizagem dos alunos e da gestão escolar. O SARESP é um dos indicadores que compõem o Índice de Desenvolvimento da Educação de São Paulo - IDESP. Mais que avaliar as escolas, o SARESP auxilia a monitorar e a traçar planos e metas para o ensino das escolas públicas paulistas.

Apresentamos a seguir resultados da unidade escolar, referentes ao SARESP, como também sucinta análise do quadro:

\section{Médias do SARESP 2014}

\begin{tabular}{|c|c|c|c|c|}
\hline $\begin{array}{c}\text { Ano de Escolaridade / } \\
\text { Componente Curricular }\end{array}$ & $3^{\circ}$ Ano & $5^{\circ}$ Ano & $7^{\circ}$ Ano & $9^{\circ}$ Ano \\
\hline Língua Portuguesa & 233,4 & 257,1 & 260,7 & 269,8 \\
\hline $\begin{array}{c}\text { Redação (nota global da } \\
\text { Rede SESI - aplicação } \\
\text { amostral) }\end{array}$ & 76,5 & 78,4 & 77,0 & 77,5 \\
\hline Matemática & 269,5 & 269,8 & 266,3 & 292,1 \\
\hline Ciências & - & - & 291,1 & 293,4 \\
\hline
\end{tabular}

O resultado acima retrata que em 2014 a unidade escolar apresentou média superior à Rede Estadual, em todas as disciplinas e séries avaliadas. Em relação a media da Rede Escolar SESI-SP apresentou média superior nos $3^{\circ}$ e $5^{\circ}$ anos do Ensino Fundamental em todas as disciplinas avaliadas, no entanto no $7^{\circ}$ e $9^{\circ}$ anos apresentou resultado discretamente inferior em Língua Portuguesa, Matemática e Ciências. 
A nota da redação reflete a média geral da Rede Escolar SESI-SP, não há o resultado específico da unidade. As produções textuais foram realizadas por amostragem, no entanto analisando as redações de nossos alunos verifica-se que há a necessidade de reforço no ensino e na avalição acerca da leitura e da escrita. Boa parte dos estudantes é incapaz de escrever sem erros ortográficos, encadear um raciocínio com princípio, meio e fim, interpretar um texto ou perceber o sentido do que é dito na aula. Há também problema na oralidade, o vocabulário é deficitário e parcela dos estudantes demonstra dificuldade em responder a uma pergunta com princípio, meio e fim.

Analisando-se o período de 2008 a 2014, verifica-se que, em Língua Portuguesa, praticamente não houve evolução nas médias das proficiências, já que a evolução no período foi de apenas 4,7 pontos. Já em Matemática, houve uma maior evolução ao longo desses anos, com saldo positivo de 22,8 pontos.

Distribuição Percentual dos Alunos nos Níveis de Proficiência

\begin{tabular}{|c|c|c|}
\hline $3^{\circ}$ Ano & Língua Portuguesa & Matemática \\
\hline Abaixo do Básico & 0,0 & 0,0 \\
\hline Básico & 2,9 & 0,0 \\
\hline Adequado & 34,3 & 17,1 \\
\hline Básico + Adequado & 37,1 & 17,1 \\
\hline Avançado & 62,9 & 82,9 \\
\hline
\end{tabular}

A escola apresentou no $3^{\circ}$ ano do Ensino Fundamental resultados satisfatórios, em que se observa uma grande concentração dos alunos no nível Avançado, nos dois componentes curriculares avaliados, o que significa que os alunos apresentam bons níveis de conhecimento sobre o sistema de escrita da Língua Portuguesa e Matemática. Contudo é importante lembrar que o baixo número de alunos que compõem o nível básico necessita de uma atenção especial.

\begin{tabular}{|c|c|c|}
\hline $\mathbf{5}^{\mathbf{A}} \mathrm{Ano}$ & Língua Portuguesa & Matemática \\
\hline Abaixo do Básico & 0,0 & 0,0 \\
\hline Básico & 6,3 & 9,7 \\
\hline Adequado & 43,8 & 48,4 \\
\hline Básico + Adequado & 50,0 & 58,1 \\
\hline Avançado & 50,0 & 41,9 \\
\hline
\end{tabular}

A exemplo da série anterior, a escola apresentou no $5^{\circ}$ ano do Ensino Fundamental resultados satisfatórios. Observa-se bom índice dos alunos no nível Avançado, nos dois componentes curriculares avaliados, o que significa que os alunos apresentam bons níveis de conhecimento sobre o sistema de escrita da Língua Portuguesa e Matemática. Contudo, se comparado ao $3^{\circ}$ ano, verifica-se uma queda no índice do nível de proficiência avançado e uma elevação no índice do nível de proficiência básico. É importante lembrar que os alunos que compõem o nível básico necessitam de uma atenção especial. 
Visão de Mundo: ler, escrever e compreender as entrelinhas do saber

\begin{tabular}{|c|c|c|c|}
\hline $7^{0}$ Ano & Língua Portuguesa & Matemática & Ciências \\
\hline Abaixo do Básico & 10,0 & 6,7 & 6,7 \\
\hline Básico & 6,7 & 26,7 & 13,3 \\
\hline Adequado & 43,3 & 46,7 & 50,0 \\
\hline Básico + Adequado & 50,0 & 73,3 & 63,3 \\
\hline Avançado & 40,0 & 20,0 & 30,0 \\
\hline
\end{tabular}

No $7^{\circ}$ ano, o resultado obtido em 2014 é menor do que o esperado para a série. Observa-se considerável percentual de alunos no nível de proficiência abaixo do básico, como também elevação no percentual do nível básico e queda no percentual do nível avançado.

\begin{tabular}{|c|c|c|c|}
\hline 90 Ano & Língua Portuguesa & Matemática & Ciências \\
\hline Abaixo do Básico & 3,1 & 0,0 & 9,4 \\
\hline Básico & 53,1 & 50,0 & 37,5 \\
\hline Adequado & 40,6 & 46,9 & 50,0 \\
\hline Básico + Adequado & 93,8 & 96,9 & 87,5 \\
\hline Avançado & 3,1 & 3,1 & 3,1 \\
\hline
\end{tabular}

O resultado aponta que no $9^{\circ}$ ano, a exemplo do $7^{\circ}$, também há alunos no nível abaixo do básico. Outro dado significativo é que o percentual de alunos no nível avançado é extremamente reduzido. Esses resultados demonstram a necessidade de aprofundamento das habilidades/competências/conteúdos trabalhados com os alunos nos anos finais do Ensino Fundamental.

Além disso, em 2014 observou-se uma queda na média geral da escola, nos $7^{\circ}$ e $9^{\circ}$ anos, em Língua Portuguesa e Matemática, quando comparado ao ano de 2013. Uma das possíveis explicações para essa queda na média pode estar no aumento discreto do percentual dos alunos nos níveis de proficiência Abaixo do Básico e Básico. Assim, reiteramos que em relação ao desempenho do $7^{\circ}$ e $9^{\circ}$ anos do Ensino Fundamental, nos componentes curriculares avaliados, pode-se observar que eles são, ainda, insatisfatórios, uma vez que ocorre significativo percentual nos níveis Abaixo do Básico e Básico de proficiência para a série.

Considerando-se os dados referentes a essas duas séries, haverá maior acompanhamento/orientação para a equipe escolar, no sentido de detectar as deficiências dos processos de ensino e aprendizagem/avaliação, em todos os componentes curriculares. Isso será feito não somente tendo em vista $07^{\circ}$ e $9^{\circ}$ anos, mas, igualmente, $06^{\circ}$ e $08^{\circ}$ anos, que são séries intermediárias de fundamental importância, nas quais são desenvolvidas habilidades/competências/conteúdos necessários para o aprofundamento das aprendizagens nos anos subsequentes. 


\section{Avaliações e relatórios internos}

Apresentamos a seguir dados referentes ao número de matriculas inicial, movimentação de alunos e rendimento escolar dos anos iniciais do Ensino Fundamental. Tais dados, associados aos resultados do Conselho de Classe Final da unidade, constituem-se em elementos valiosos para detectar problemas, definir encaminhamentos, analisar variáveis e definir metas.

\begin{tabular}{|c|c|c|c|c|c|c|c|}
\hline $\begin{array}{l}\text { Sériel } \\
\text { Ano }\end{array}$ & $\begin{array}{l}\text { Matriculas } \\
\text { iniciais }\end{array}$ & Evasão & Transf. & $\begin{array}{l}\text { Matrículas } \\
\text { finais }\end{array}$ & Disciplinas & Aprov. & Reprov. \\
\hline \multirow{4}{*}{$1^{\circ}$ ano } & \multirow{4}{*}{32} & \multirow{4}{*}{0} & \multirow{4}{*}{1} & \multirow{4}{*}{31} & Linguagens & 30 & 1 \\
\hline & & & & & Matemática & 30 & 1 \\
\hline & & & & & $\begin{array}{l}\text { Ciências } \\
\text { Humanas }\end{array}$ & 30 & 1 \\
\hline & & & & & $\begin{array}{l}\text { Ciências da } \\
\text { Natureza }\end{array}$ & 30 & 1 \\
\hline \multirow{4}{*}{$2^{\circ}$ ano } & \multirow{4}{*}{32} & \multirow{4}{*}{0} & \multirow{4}{*}{0} & \multirow{4}{*}{32} & Linguagens & 32 & - \\
\hline & & & & & Matemática & 32 & - \\
\hline & & & & & $\begin{array}{l}\text { Ciências } \\
\text { Humanas }\end{array}$ & 32 & - \\
\hline & & & & & $\begin{array}{l}\text { Ciências da } \\
\text { Natureza }\end{array}$ & 32 & - \\
\hline \multirow{4}{*}{$3^{\circ}$ ano } & \multirow{4}{*}{35} & \multirow{4}{*}{0} & \multirow{4}{*}{0} & \multirow{4}{*}{35} & Linguagens & 35 & - \\
\hline & & & & & Matemática & 35 & - \\
\hline & & & & & $\begin{array}{l}\text { Ciências } \\
\text { Humanas }\end{array}$ & 35 & - \\
\hline & & & & & $\begin{array}{l}\text { Ciências da } \\
\text { Natureza }\end{array}$ & 35 & $=$ \\
\hline \multirow{4}{*}{$4^{\circ}$ ano } & \multirow{4}{*}{33} & \multirow{4}{*}{0} & \multirow{4}{*}{1} & \multirow{4}{*}{32} & Linguagens & 32 & - \\
\hline & & & & & Matemática & 32 & - \\
\hline & & & & & $\begin{array}{l}\text { Ciências } \\
\text { Humanas }\end{array}$ & 32 & - \\
\hline & & & & & $\begin{array}{l}\text { Ciências da } \\
\text { Natureza }\end{array}$ & 32 & - \\
\hline \multirow{4}{*}{$5^{\circ}$ ano } & \multirow{4}{*}{33} & \multirow{4}{*}{0} & \multirow{4}{*}{1} & \multirow{4}{*}{32} & Linguagens & 32 & - \\
\hline & & & & & Matemática & 32 & - \\
\hline & & & & & $\begin{array}{l}\text { Ciências } \\
\text { Humanas }\end{array}$ & 32 & - \\
\hline & & & & & $\begin{array}{l}\text { Ciências da } \\
\text { Natureza }\end{array}$ & 32 & - \\
\hline
\end{tabular}

Verifica-se que nos anos iniciais do Ensino Fundamental os resultados da avaliação interna correspondem aos resultados da avaliação externa. $O$ aproveitamento dos alunos é satisfatório e atinge 0 índice de aprovação de 99,39\%, o que vai ao encontro das metas estabelecidas no plano de gestão escolar. Não há caso de evasão e as transferências ocorreram por mudança de munícipio.

Passamos a seguir à análise dos dados referentes ao número de matriculas inicial, movimentação de alunos e rendimento escolar dos anos finais do Ensino Fundamental: 
Visão de Mundo: ler, escrever e compreender as entrelinhas do saber

\begin{tabular}{|c|c|c|c|c|c|c|c|}
\hline $\begin{array}{l}\text { Sériel } \\
\text { Ano }\end{array}$ & $\begin{array}{l}\text { Matriculas } \\
\text { iniciais }\end{array}$ & Evasão & Transf. & $\begin{array}{l}\text { Matriculas } \\
\text { finais }\end{array}$ & Disciplinas & Aprov. & Reprov. \\
\hline \multirow{8}{*}{$6^{\circ}$ ano } & \multirow{8}{*}{32} & \multirow{8}{*}{0} & \multirow{8}{*}{0} & \multirow{8}{*}{32} & Português & 32 & - \\
\hline & & & & & LEM-Inglês & 32 & - \\
\hline & & & & & Arte & 32 & $=$ \\
\hline & & & & & Ed. Física & 32 & - \\
\hline & & & & & Matemática & 32 & - \\
\hline & & & & & Ciências & 32 & $=$ \\
\hline & & & & & História & 32 & $=$ \\
\hline & & & & & Geografia & 32 & - \\
\hline \multirow{8}{*}{$7^{\circ}$ ano } & \multirow{8}{*}{32} & \multirow{8}{*}{0} & \multirow{8}{*}{2} & \multirow{8}{*}{30} & Português & 27 & 3 \\
\hline & & & & & LEM-Inglês & 27 & 3 \\
\hline & & & & & Arte & 27 & 3 \\
\hline & & & & & Ed. Física & 30 & - \\
\hline & & & & & Matemática & 27 & 3 \\
\hline & & & & & Ciências & 27 & 3 \\
\hline & & & & & História & 27 & 3 \\
\hline & & & & & Geografia & 27 & 3 \\
\hline \multirow{8}{*}{$8^{\circ}$ ano } & \multirow{8}{*}{32} & \multirow{8}{*}{0} & \multirow{8}{*}{0} & \multirow{8}{*}{32} & Português & 28 & 4 \\
\hline & & & & & LEM-Inglês & 28 & 4 \\
\hline & & & & & Arte & 28 & 4 \\
\hline & & & & & Ed. Física & 32 & 4 \\
\hline & & & & & Matemática & 28 & 4 \\
\hline & & & & & Ciências & 29 & 3 \\
\hline & & & & & História & 28 & 4 \\
\hline & & & & & Geografia & 28 & 4 \\
\hline \multirow{8}{*}{$9^{\circ}$ ano } & \multirow{8}{*}{35} & \multirow{8}{*}{0} & \multirow{8}{*}{1} & \multirow{8}{*}{34} & Português & 31 & 3 \\
\hline & & & & & LEM-Inglês & 31 & 3 \\
\hline & & & & & Arte & 31 & 3 \\
\hline & & & & & Ed. Física & 34 & $=$ \\
\hline & & & & & Matemática & 31 & 3 \\
\hline & & & & & Ciências & 31 & 3 \\
\hline & & & & & História & 31 & 3 \\
\hline & & & & & Geografia & 32 & 2 \\
\hline
\end{tabular}

Do $6^{\circ}$ ao $9^{\circ}$ ano observa-se que os resultados da avaliação interna não correspondem aos resultados da avaliação externa. $O$ índice de aprovação dos anos finais é inferior ao índice dos anos iniciais, no entanto considerando-se o percentual de alunos nos níveis de proficiência abaixo do básico e básico no resultado da avaliação externa, o índice de aprovação é considerado alto: 92,19\%. Cabe aí uma análise aprofundada da concepção de ensino e do nível de exigência da avaliação realizada pela equipe docente dos referidos anos. Cabe ressaltar, no entanto, que do índice de aprovação supracitado, 22,65\% corresponde à promoção pelo Conselho de Classe. Este alto índice de aprovação pelo Conselho provêm da dificuldade de interpretação de enunciados como também da baixa qualidade das produções textuais, o que vai de encontro às metas estabelecidas no plano de gestão escolar.

Pela análise dos dados de evasão e transferência verifica-se que o número de alunos não diminui ao longo da 
escolaridade, o que revela que não há um funil de reprovação ou de evasão. 0 índice de evasão em 2014 foi de $0 \%$ e o de transferência foi de 2,05\%, considerando-se do $1^{\circ}$ ao $9^{\circ}$ ano. Como dito acima, todos os casos de transferência ocorreram por mudança de município. Verifica-se que não há distorção idade/série e que também não há determinada disciplina que mais impacta nos índices de reprovação.

Através de pesquisa realizada com alunos e responsáveis verifica-se a satisfação com o ensino oferecido e as aulas ministradas pelos professores, apesar de $20 \%$ da amostra desejar maior utilização de recursos no desenvolvimento das aulas. A pesquisa indica que nossos alunos, como também seus responsáveis, não se tornaram leitores. O número de livros lidos corresponde ao número de livros solicitados pelo professor. Ao mesmo tempo em que leem mais por obrigação, que por prazer, estão insatisfeitos com o acervo de livros do Centro Educacional. Este dado não favorece a formação do sujeito leitor. Verifica-se que $96,7 \%$ tem acesso à internet, mas a utilização da rede ocorre principalmente para navegação nas redes sociais. Apenas $16,7 \%$ a utilizam com maior frequência para pesquisas. Não são frequentadores assíduos de salas de cinema ou de teatro. Mesmo com espetáculos teatrais semanais e gratuitos no Sítio do Pica Pau Amarelo, na cidade vizinha de Taubaté, a frequência é baixa $(30,6 \%)$. Assistem a peças teatrais se realizadas na escola $(57,1 \%)$. São preocupados com o que ocorre no mundo $(84,2 \%)$, tendo na televisão ou rádio a principal fonte de informação. Não são leitores de jornal e nem de revistas semanais informativas. Apenas 14,2\% participam da elaboração do jornal da escola.

A pesquisa foi realizada através de formulário do Google Drive e encaminhamento do link aos respondentes. Para definição do tamanho da amostra, utilizamos a fórmula elaborada por Cochran. A escola possui duzentos e noventa e dois alunos matriculados e optamos por ouvir também responsáveis. Consideramos assim a população de 584 pessoas e, podendo admitir um erro de até 10\%, a amostra foi calculada em 120 pessoas, sendo que todas participaram. Optamos pela amostra probabilística, sendo sorteados alunos de todos os anos. Do $1^{\circ}$ ao $3^{\circ}$ ano os responsáveis responderam a pesquisa ( $30 \%$ da amostra), e do $5^{\circ}$ ao $9^{\circ}$ ano, os próprios alunos a responderam (70\% da amostra).

Analisando o baixo rendimento dos alunos dos anos finais, junto aos professores, os mesmos atribuem 0 resultado inadequado à ausência de rotina de estudo, índice insatisfatório na realização de lições de casa e pesquisas como também desinteresse pela leitura. Argumentam ainda a falta de apoio da família e baixa expectativa educacional dos pais.

Um aspecto preocupante, que não consta na pesquisa, consiste na resistência do professor em participar dos escassos momentos de discussões pedagógicas coletivas, em virtude de lecionar em outras redes.

Preocupa-nos sobremaneira o desinteresse dos alunos pela leitura, pois a leitura e a compreensão dos textos devem ser à base da aprendizagem. 0 aluno que está nos anos finais do ensino fundamental iniciou sua escolarização no próprio Centro Educacional, e não desenvolveu um comportamento leitor e ou escritor.

A escola se debate com um sério problema da questão educacional: o nível de aprendizagem de parcela de alunos não corresponde aos padrões básicos exigidos. No que se refere ao ato de ler com fluência e significação estamos distantes do desejado. Muitos alunos não conseguem compreender os vários sentidos existentes em um texto e fazer correlações. A alfabetização compreende 0 ato de ler, escrever, interpretar e reproduzir criticamente o lido. Neste sentido, uma intervenção pedagógica se faz necessária.

\section{Principais problemas identificados}

Após análise dos resultados da escola, da pesquisa de satisfação e dos relatos dos docentes, verifica-se a necessidade de uma ressignificação do processo de ensino e aprendizagem a fim de elevarmos os níveis de proficiências dos alunos. Cabe ressaltar que o desempenho da leitura e compreensão interfere na aprendizagem de todas as disciplinas.

Apontamos a seguir os principais problemas identificados:

- Ausência do sujeito-leitor, que a cada ato de leitura aprende a superar a posição ingênua por outra mais crítica e autônoma no modo de pensar, agir e ser, compreendendo, interpretando e ampliando sua visão de mundo.

- Baixo nível de proficiência em Língua Portuguesa. 
- Baixa utilização de recursos didáticos pelos professores no desenvolvimento das aulas.

- Insatisfação dos alunos e responsáveis com o acervo de livros da unidade escolar, ocasionando poucos empréstimos e baixo índice de leitura.

- Resistência do professor em participar das discussões pedagógicas coletivas, em virtude de lecionar em outras redes.

A partir dos problemas elencados, utilizamos a matriz GUT, a fim de definir as prioridades:

\begin{tabular}{|l|c|c|c|c|c|}
\hline \multicolumn{1}{|c|}{ Problemas } & G & U & T & GxUxT & Prioridade \\
\hline $\begin{array}{l}\text { Resistência do professor em participar das } \\
\text { discussões pedagógicas coletivas. }\end{array}$ & 4 & 5 & 4 & 80 & $2^{0}$ \\
\hline Ausência do sujeito leitor. & 5 & 5 & 5 & 125 & $1^{0}$ \\
\hline $\begin{array}{l}\text { Baixo nível de proficiência em Língua } \\
\text { Portuguesa. }\end{array}$ & 5 & 5 & 5 & 125 & $1^{0}$ \\
\hline $\begin{array}{l}\text { Baixa utilização de recursos didáticos pelos } \\
\text { professores. }\end{array}$ & 4 & 5 & 4 & 80 & $2^{0}$ \\
\hline $\begin{array}{l}\text { Insatisfação dos alunos e responsáveis com } \\
\text { 0 acervo de livros da unidade. }\end{array}$ & 4 & 4 & 4 & 64 & $3^{0}$ \\
\hline
\end{tabular}

\section{Detalhamento do problema}

Os dois problemas priorizados estão relacionados, ou seja, ausência do sujeito leitor e baixo nível de proficiência em Língua Portuguesa.

Utilizou-se o Diagrama de Causa e Efeito para detalhar o problema:

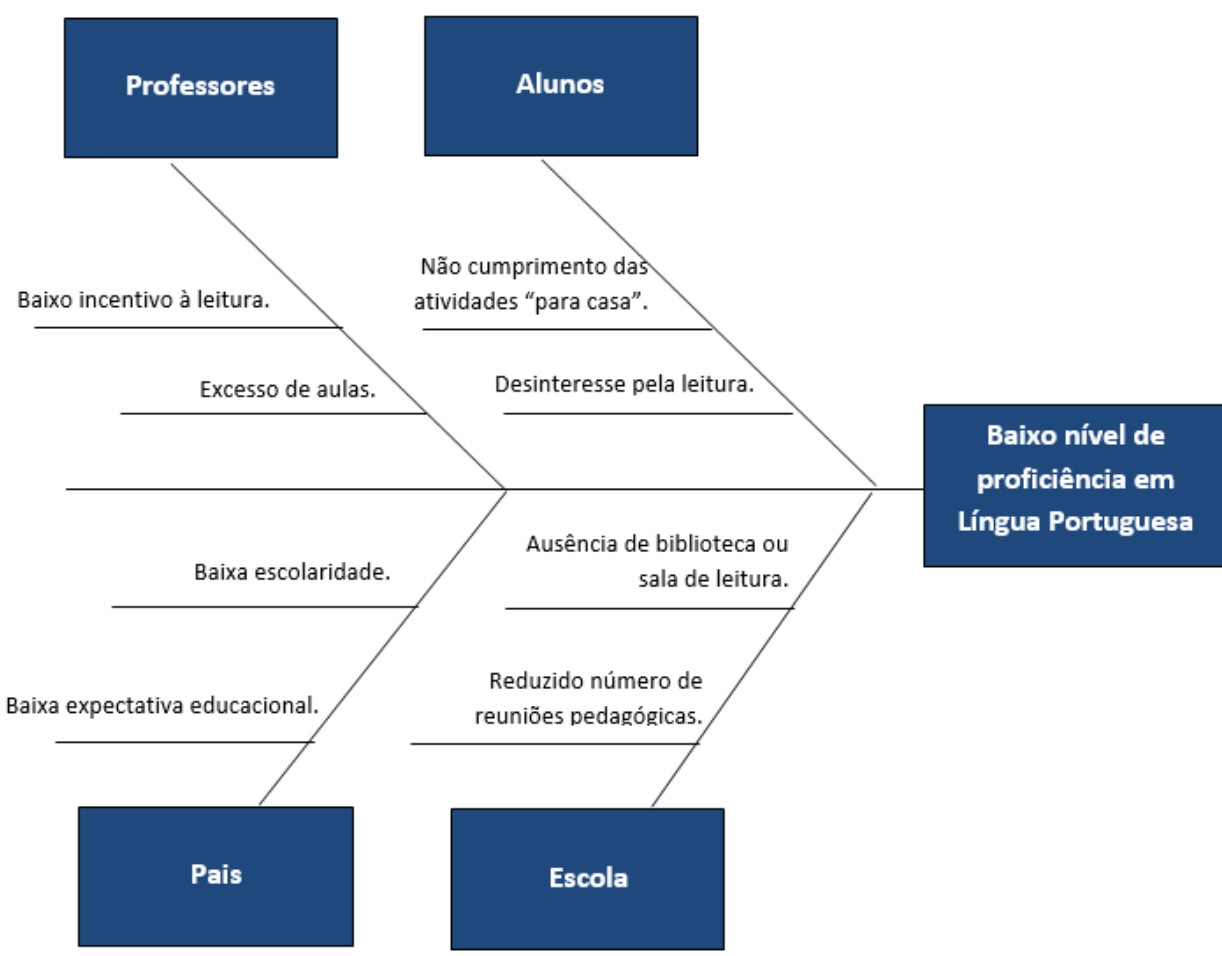




\section{Análise SWOT}

A partir das pesquisas realizadas pela equipe escolar e das discussões sobre o contexto da escola, foi desenvolvida a seguinte Matriz SWOT.

\begin{tabular}{|c|c|c|}
\hline & Aspectos favoráveis & Aspectos desfavoráveis \\
\hline \multirow[b]{2}{*}{ 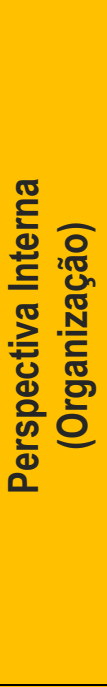 } & FORÇAS & FRAQUEZAS \\
\hline & $\begin{array}{l}\text { - União da equipe. } \\
\text {. Comprometimento da equipe. } \\
\text {. Motivação da equipe. } \\
\text {. Formação continuada em serviço das } \\
\text { equipes docente/gestora. } \\
\text { profissional. } \\
\text {. Recursos pedagógicos e tecnológicos. } \\
\text {. Compartilhamento de ideias. }\end{array}$ & $\begin{array}{l}\text { Baixo incentivo à leitura pela equipe } \\
\text { docente. } \\
\text { Ausência de biblioteca ou sala de leitura. } \\
\text { Acervo de livros deficitário. } \\
\text { Baixo número de docentes que utilizam } \\
\text { recursos pedagógicos diferenciados em } \\
\text { suas práticas pedagógicas. } \\
\text {.Desinteresse do aluno pela leitura. } \\
\text { Descompromisso dos alunos dos anos } \\
\text { finais com o processo de aprendizagem. }\end{array}$ \\
\hline \multirow[b]{2}{*}{ 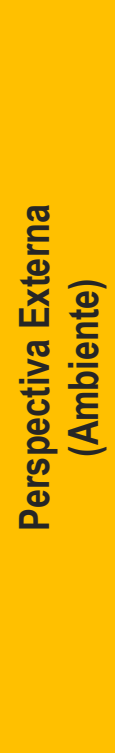 } & OPORTUNIDADES & AMEAÇAS \\
\hline & $\begin{array}{l}\text { Reconhecimento da "marca" SESI. } \\
\text { Valorização da escola pela comunidade } \\
\text { local. } \\
\text {. Crescente procura por vagas. } \\
\text {. Parcerias estabelecidas com Prefeitura } \\
\text { Municipal e Indústrias do município. } \\
\text {. Congressos Educacionais proporcionados } \\
\text { pela Rede Escolar SESI-SP. } \\
\text {. Parceria estabelecida com a Editora SESI. } \\
\text {. Parceria estabelecida com o "Sitio do Pica } \\
\text { Pau Amarelo" }\end{array}$ & $\begin{array}{l}\text { Profissionais experientes que solicitam } \\
\text { transferência em virtude de passarem em } \\
\text { concursos da Prefeitura de São José dos } \\
\text { Campos. } \\
\text { plevada taxa de desemprego dos } \\
\text { pais/responsáveis. } \\
\text { Desinteresse de pais/responsáveis em } \\
\text { participarem de ações dentro da escola, } \\
\text { como também em atividades educativas } \\
\text { junto aos filhos. }\end{array}$ \\
\hline
\end{tabular}

Analisando a Matriz SWOT observa-se que o Centro Educacional apresenta mais forças e oportunidades que fraquezas e ameaças. Verifica-se, portanto, resultado positivo.

As forças e oportunidades diferenciam a unidade escolar das escolas do entorno e favorecem 0 desenvolvimento do processo de ensino e aprendizagem. A equipe é unida, comprometida, motivada e está em constante busca por aperfeiçoamento profissional.

\section{Ações corretivas}

Visando preparar a organização para o desenvolvimento do projeto, no intuito de combater as fraquezas e reduzir os possíveis impactos das ameaças, foram definidas as seguintes ações:

- Sensibilizar e capacitar equipe docente para o trabalho de mediação de leitura. 
- Propiciar espaço adequado ao desenvolvimento do trabalho com a leitura.

- Ampliar o acervo de livros

- Elaborar junto à Coordenação Pedagógica programa de atividades extraclasse e incentivar junto ao corpo docente a utilização de materiais pedagógicos diversificados, visando ampliar o capital cultural do aluno e aprimorar o desempenho pedagógico.

- Disponibilizar mural para que os pais desempregados divulguem e ofereçam seus serviços.

- Promover palestras e cursos de geração de renda em parceria com o Centro de Atividades do SESI, visando melhor qualidade de vida das famílias e aproximação das mesmas às ações da escola.

\section{Oportunidade identificada}

Pensando em possíveis soluções para elevar o nível de proficiência dos alunos em Língua Portuguesa, discutimos a necessidade de ressignificação do trabalho do professor, para que este, independente de sua área de atuação, utilize o ensino da leitura e da escrita como prática social. Acreditamos que temos o dever, como educadores, de oferecer aos alunos condições adequadas de aprendizagem da leitura e da escrita, como possibilidade de efetiva participação social e conquista de direitos. Visamos formar sujeitos letrados, que pratiquem a leitura e a escrita em suas vidas, que as utilizem como forma de interação com o mundo e com outros sujeitos, e se sintam assim também sujeitos. A escrita é um fator de interação entre os homens e, a leitura, uma forma eficaz de entendimento do mundo.

Cito Jean Paul Sartre, para a ideia da proposta: "Os livros são meus pássaros, com eles aprendi a voar. E uma biblioteca é um espelho, onde vi o universo refletido". É nessa visão que segue nossa proposta. Compartilhar com os alunos, e envolver seus responsáveis, uma proposta à leitura de literatura, onde possam voar, ampliando a visão para além da competência leitora e escritora e do próprio processo de letramento. Buscamos alimentar a imaginação dos alunos, para que experimentem o prazer que a leitura pode lhes oferecer. Para que descubram os encantos da literatura como uma forma de arte, arte que possibilita maior conhecimento de si e do mundo. Para que se tornem pessoas mais críticas, mais criativas e mais sensíveis.

A vantagem da proposta é que desenvolvendo o comportamento leitor, as causas do déficit na leitura, dificuldades de interpretação, escrita e oralidade são solucionadas. Além disso, a proposta de leitura à literatura reúne ações de modo integrado à ideia central. Após as ideias colocadas em prática esperamos os seguintes resultados: desenvolvimento do pensamento letrado nos alunos, aperfeiçoamento da compreensão leitora, escritora, fluência e expressividade na leitura e utilização da leitura como fonte de prazer e informação.

A ideia central do projeto, portanto, é a formação do aluno leitor e consequente melhoria de seu desempenho pedagógico.

Nosso objetivo é realizar atividades extraclasses no contra turno, durante os anos de 2015, 2016 e 2017, para elevar em 40\% o nível de proficiência dos alunos do Ensino Fundamental em Língua Portuguesa, na avaliação externa SARESP, tendo o resultado de 2014 como referência inicial e a média obtida em 2017 como referência final. 


\section{Detalhamento do produto/serviço e/ou processo}

O Centro Educacional carece de um projeto de formação do sujeito-leitor. Diante da complexidade do mundo atual a escola é desafiada para o empreendimento de uma nova concepção de ensino, que efetivamente estabeleça relação entre o conhecimento e a vida cotidiana. Ao dominar a leitura, abre-se ao aluno a possibilidade de adquirir conhecimentos, alargar a visão de mundo, desenvolver raciocínio e participar ativamente da vida social.

O Projeto "Visão de Mundo - Ler, escrever e compreender as entrelinhas do saber" é um projeto de incentivo e promoção da leitura, que concebe 0 ato de ler como um ato de compreensão e interação do leitor com a realidade e com o mundo que o cerca. Tem como foco fazer da escola uma comunidade de leitores e escritores, favorecendo a formação de seres humanos competentes, críticos, capazes de ler as entrelinhas e de se posicionarem frente aos autores e textos com os quais interagem. Através da literatura propõe a leitura para ampliar o mundo imaginário e para chegar ao prazer do texto. Visa constituir um espaço interativo entre as diversas manifestações de sentido, como forma de desenvolver múltiplas linguagens como a literária, a cênica, a plástica visual e a audiovisual, de modo a estimular a prática de leitura de forma crítica e criativa. Visa ainda propiciar a interação, manipulação, compreensão, recriação e criação de diversas formas de textos verbais e não verbais através de oficinas e atividades desenvolvidas na sala de leitura. Cabe ressaltar que a sala de leitura se constituirá em novo ambiente da unidade escolar.

O Projeto prevê ainda leitura compartilhada entre pais e alunos, para que ambos leiam as mesmas obras e possam discutir as várias possibilidades de interpretação, criando assim um ciclo de incentivo à leitura. Consequentemente, a partir das leituras constantes, o aluno será capaz de produzir textos melhores, mais concisos, coerentes e criativos.

\section{Foco do projeto}

Série ou conjunto de séries beneficiadas: $1^{0}$ ao $9^{\circ}$ ano do Ensino Fundamental.

Disciplina ou conjunto de disciplinas trabalhadas: Língua Portuguesa, como eixo principal, no entanto todas as disciplinas serão envolvidas, uma vez que ensinar a ler é tarefa de todas as disciplinas.

\section{Etapas do projeto}

O projeto será composto pelas seguintes etapas:

\section{Etapa 1 - Ação-Capacita-Divulga-Ação}

Objetivo: Elaborar um projeto de formação de leitores e sensibilizar e capacitar $100 \%$ da equipe docente para as ações, envolvendo também a comunidade.

Impacto na aprendizagem: Desenvolvimento da competência leitora e escritora no aluno, através de um trabalho planejado e integrado da equipe docente, que efetivamente amplie as habilidades de leitura e de produção de textos.

\section{Atividade 1.1 - "Organiza - Ação"}

Descrição: Sistematização do projeto pela equipe gestora e preparação do material de capacitação aos docentes.

Duração: Meses de janeiro e fevereiro de 2015.

Recursos necessários: Notebook / Impressora / Papel Sulfite.

Equipe envolvida: Diretor de Escola / Coordenador Pedagógico.

\section{Atividade 1.2 - "Forma-Ação"}

Descrição: Com novas propostas de formação, nesta atividade o Coordenador Pedagógico tem um papel fundamental a cumprir. Cabem a ele conduzir as discussões e orientar sobre o planejamento e as intervenções. Outro profissional essencial para o trabalho é o professor de Língua Portuguesa, que se colocará como um parceiro mais experiente quando a leitura entra em cena. 
$\mathrm{Na}$ capacitação pelo coordenador pedagógico serão considerados aos professores os seguintes princípios e orientações didáticas:

$\checkmark$ Diversidade: variação e diversificação dos textos, das leituras, dos usos dos textos, dos grupos, das situações propostas, dos desafios e das dinâmicas de trabalho.

$\checkmark$ Continuidade: importância da sequência às propostas didáticas, desenvolvendo e dando fechamento ao que foi iniciado. Evitar práticas isoladas que não mantém relação umas com as outras.

$\checkmark$ Simultaneidade: faz-se necessário que coexistam diferentes modalidades e propostas de trabalho num mesmo período.

$\checkmark$ Assiduidade: necessidade de se retornar às mesmas práticas, como um espiral em que se vai e volta, revendo o que já se fez e viveu, mas sempre ampliando e diversificando.

$\checkmark$ Progressão: importância de oportunizar avanços progressivos, apresentando propostas com desafios ou níveis de complexidade cada vez maiores.

Será enfatizado que a leitura e a escrita são hoje um dos maiores desafios da escola e que a leitura, quando estimulada de forma criativa, possibilita a redescoberta do prazer de ler, contribui para a utilização da escrita em contextos sociais e a inserção do aluno no mundo letrado.

Através da técnica de criatividade Brainstorming serão propostas a geração de ideias inovadoras, referentes ao motivo dos alunos começarem a perder o gosto pela leitura e pelos estudos, por volta dos onze/doze anos.

De posse da análise dos resultados, será esclarecido que cabe à escola, em meio a tantas mudanças tecnológicas e sociais, estimular a leitura, melhorar as estratégias, principalmente de compreensão, e oferecer muitos e variados textos. Dos caminhos a seguir, será esclarecido que dois favorecem a intimidade dos alunos com o texto: ensinar a estabelecer previsão e inferência, estratégias que são invocadas na prática da leitura, logo no primeiro contato com o texto, e que devem ser provocadas conscientemente pelo professor na prática de leitura.

O docente será ainda orientado que para uma atividade de leitura bem planejada deverá pesquisar textos e se preocupar em:

$\checkmark$ Ter um objetivo bem definido para desenvolver com o aluno.

$\checkmark$ Escolher textos à altura do repertório dos alunos para que o diálogo com a leitura seja produtivo, mas também outros de leitura complexa, que mediados pelo professor permitam tornar o diálogo possível.

$\checkmark$ Ativar o conhecimento prévio dos alunos, ensinando a fazer perguntas sobre o texto, para aumentar as possibilidades de compreensão do mesmo.

$\checkmark$ Fazer hipóteses e previsões sobre o texto a ser lido. Ensinar a estabelecer previsões, baseando-se no gênero, no título, no subtítulo, nas ilustrações, etc.

$\checkmark$ Favorecer a participação do aluno por meio de perguntas e situações em que ele tenha de fazer uso de estratégias que the facilitem a compreensão do texto.

$\checkmark$ Articular diferentes situações de leitura - silenciosa, coletiva, oral, individual e compartilhada - e encontrar os textos mais adequados para alcançar os objetivos.

$\checkmark$ Estimular o grupo a sempre trocar ideias e discutir o que foi lido.

$\checkmark$ Propor trabalhos em que os alunos precisem ler para seguir instruções, revisar a própria escrita, praticar a leitura em voz alta e memorizar.

Será esclarecido ainda ao professor que 0 aluno somente terá habilidades de leitura se tiver primeiramente 0 hábito de ler e que para despertar o gosto pela leitura no aluno ele deve ter a autonomia de escolher o que 
quer ler. O professor, portanto, não deve ser autoritário a ponto de escolher sozinho o que os alunos devem ou não ler. Deve levar em conta as diversidades dentro da sala de aula e valorizar os gostos e opiniões formadas pelos alunos.

Ainda nesta etapa de mobilização e capacitação da equipe docente serão debatidas e construídas com a equipe de professores as atividades de mobilização dos discentes para a leitura: criação de espaços, divulgação de acervo, contato com escritores, artistas, ilustradores e outros profissionais envolvidos com a leitura, escrita e oralidade, além de outras linguagens, exposições de textos, entrevistas, utilização de outros espaços da escola na divulgação...

Serão recebidas as sugestões dos professores referentes às aquisições de livros, como mais uma contribuição para a ampliação do acervo.

Duração: 24 horas/aula, ao final do mês de fevereiro, no período estipulado à capacitação da equipe docente.

Recursos necessários: notebook/Datashow/ propostas de ações para debate.

Equipe envolvida: Diretor de Escola / Coordenador Pedagógico / Equipe Docente.

\section{Atividade 1.3 - "Ação-Família"}

Descrição: visando ao envolvimento da comunidade, os pais serão convidados a conhecerem o projeto. Na oportunidade serão esclarecidos da importância da formação do sujeito leitor e serão convidados a compartilharem da seguinte proposta: troque uma hora de TV por uma hora para ler. A ideia é que pais e filhos se reúnam uma hora por dia para que juntos leiam os mesmos títulos e descubram o prazer das histórias.

Duração: 4 horas/aula, ao término da semana de capacitação de docentes.

Recursos Necessários: notebook/Datashow.

Equipe envolvida: Diretor de Escola / Coordenador Pedagógico / Equipe Docente/ Pais e ou responsáveis.

\section{Etapa 2 - Muitos textos...tantas palavras}

Objetivo: Ampliar em 100\% o acervo de livros da caixa estante, criar espaço de leitura e familiarizar equipes discente e docente com a sala de leitura.

Impacto na aprendizagem: Estímulo à leitura e atividades culturais como forma de melhorar o desempenho escolar, articulando leitura, oralidade e escrita de maneira integrada a outras formas de linguagens.

\section{Atividade 2.1 - "Mundo da leitura...leitura do Mundo"”"}

Descrição: Em parceria com a Editora SESI e com a Supervisão de Bibliotecas da Rede Escolar SESI-SP, será ampliado em 100\% o acervo de livros da unidade. Paralelamente haverá aquisição de assinaturas de revistas, jornais e gibis, visando a um acervo atualizado, que incorpore a literatura da melhor qualidade: livros de literatura, livros informativos, dicionários, periódicos, textos teatrais, letras de músicas, revistas, jornais, poesias, quadrinhos...

Duração: Janeiro a dezembro de 2015.

Recursos necessários: livros, revistas, jornais, gibis.

Equipe envolvida: Diretor Escolar / Coordenador Pedagógico / Supervisor de Biblioteca da Rede Escolar SESI-SP / Professor Auxiliar de Docente.

\section{Atividade 2.2 - "Livro vai, livro vem...nesse espaço eu leio e você também"}

Descrição: Criação de um espaço de leitura. A sala de aula $n .{ }^{\circ} 6$, que não é utilizada, será transformada em sala de leitura. Com a ação disponibilizaremos aos alunos um ambiente eficiente e aconchegante, que favoreça a formação e desenvolvimento do prazer pela leitura e pela busca de saberes. 0 próprio aluno poderá manusear os materiais, dispostos nas estantes, criando uma relação de respeito pelo livro, pela leitura e pelo conhecimento. 
Duração: Janeiro e fevereiro de 2015.

Recursos necessários: estantes, tapetes de EVA, almofadas, Datashow, computador, ponto de rede de internet, TV, mesas, cadeiras.

Equipe envolvida: Diretor Escolar / Coordenador Pedagógico / Equipe de manutenção do Centro de Atividades SESI - Taubaté, ao qual a escola é jurisdicionada.

\section{Atividade 2.3 - "Ler e Conhecer"}

Descrição: Sensibilização e ambientação dos alunos com o espaço da sala de leitura, sua função, organização, regras e funcionamento e familiarização com o acervo da sala, reconhecendo autores, tipos de livros, coleções...

Duração: Sete dias, com início na terceira semana de fevereiro de 2015.

Recursos necessários: Datashow, para exibição de um vídeo de sensibilização.

Equipe envolvida: Equipe Discente / Equipe Docente / Coordenador Pedagógico/ Diretor de Escola.

\section{Etapa 3 - Ler com Arte? Quero fazer parte!}

Objetivo: Possibilitar a 100\% da equipe discente a participação em atividades de leitura e vivências artísticas que desenvolvam a interpretação, a compreensão, a criatividade e a produção de textos.

Impacto na aprendizagem: Alunos que ouvem, leem, interagem, escrevem e curtem histórias sempre apresentam maior facilidade na compreensão dos textos, como também maior facilidade em todos os aspectos e objetivos da escolaridade.

\section{Atividade 3.1 - "Literatura? Muito prazer!"}

Descrição: Por se tratar de um projeto de leitura, o texto verbal e escrito serão prioridades, no entanto poderão ser articuladas a esses textos outras formas de linguagem, inclusive não verbais, que revelam diversas visões de mundo.

$\mathrm{Na}$ atividade será considerada a diversificação de textos, de leituras, de usos dos textos, das dinâmicas, das expressões corporais, das situações propostas e desafios. Serão propostas atividades com níveis de complexidade cada vez maiores, oportunizando assim avanços progressivos, conforme princípios e orientações trabalhados na capacitação.

Seguem abaixo propostas a serem desenvolvidas no decorrer da etapa Ler com Arte? Quero fazer parte! 0 aprofundamento de cada proposta será em decorrência do ano de escolaridade cursado. À medida do desenvolvimento do projeto poderão ser acrescentadas novas propostas.

\section{Recreio na sala de leitura:}

Organização da sala de leitura para atividades diversificadas: contação de histórias, exploração de novos materiais, jogos, organização diferente do espaço com tendas ou varais, caça ao tesouro, apresentação de vídeo clip, etc.

\section{Caça ao tesouro das letras:}

O que é uma caça ao tesouro? Quem esconde tesouros? Que histórias conhecem que falam sobre tesouros escondidos?

A partir da conversa inicial selecionar livros, materiais, histórias e filmes que tenham como tema tesouros escondidos.

Contos de piratas: o que são contos? Pesquisar e ler contos de piratas.

Escrever pequenos contos de piratas.

Como se acha um tesouro? Introduzir a leitura, pesquisa e elaboração de mapas. 
Observar Atlas diversificados, analisar mapas antigos, fazer o mapa da escola e da sala de leitura.

Montar equipes que irão criar códigos, mapas e esconder tesouros na sala de leitura para as outras equipes encontrarem, estimulando a colocação das pistas em livros de determinados autores, espalhadas pela escola, etc. Os prêmios serão gibis, revistas de passatempo, livros, material escolar, fantoches, etc.

\section{Mesmo tema, muitos olhares:}

A partir de um tema escolhido pelos alunos, dividir a turma em grupos, localizar, analisar e compartilhar (em rodas de conversa e exposição de materiais) como este tema é tratado em diversos tipos textuais e linguagens: poesia, gibis, obras de arte, letras de música, fotografias, jornais, revistas, folders, etc.

Após a exposição e discussão sobre as várias formas de representação, cada grupo irá escolher uma delas para pesquisar e, a partir da pesquisa, realizar uma recriação do tema tendo como resultado um produto final para ser apresentado: um clipe, um livro, um folder, uma poesia, uma música, etc.

Apresentação de resultados para outras turmas e exposição.

\section{Texto dramático:}

Pesquisar sobre a história do cinema, buscando materiais sobre o assunto na sala de leitura.

Expor algumas informações e montar cartazes sobre a história do cinema.

Assistir trechos de filmes antigos mudos; conversar sobre o filme, suas características, os recursos utilizados, etc.

Criar diálogos para os trechos dos filmes apreciados.

Visitar o Museu Mazzaropi, que retrata o cinema antigo, na cidade de Taubaté, e estabelecer relações de tempo e de recursos.

Inserir a análise e apreciação de textos teatrais e roteiros.

Trabalhar com um texto de um autor do Vale do Paraíba ( Monteiro Lobato).

. Organizar uma palestra com o responsável pela criação e montagem das peças teatrais do Sítio do Pica Pau Amarelo, antiga residência de Monteiro Lobato, localizado na cidade de Taubaté.

Pesquisar e conversar sobre alguns materiais que serão utilizados na palestra: convites, cartazes de divulgação, entrevistas, funcionamento da máquina fotográfica, funcionamento da filmadora, bilhetes, cartas de agradecimento, etc.

Confeccionar os materiais necessários.

Ler uma pequena biografia de Monteiro Lobato.

Criar biografias individuais.

Assistir e documentar a palestra com o responsável pela criação e montagem das peças teatrais do Sitio do Pica Pau Amarelo no pátio da escola: Como é fazer teatro para crianças? Escreve o roteiro sozinho? Escreve no computador? Gosta de ler? O que? Quando?...

Assistir a uma peça teatral no Sítio ou no Teatro do SESI em São José dos Campos.

Pesquisar e conversar sobre os conteúdos que envolvem o Teatro - espaço cênico, personagem e ação teatral - lendo, vendo imagens, retomando a peça assistida, etc.

Iniciar a montagem de uma ou duas peças teatrais (dependendo do número de alunos e da peça) - definir temas, títulos, personagens, tipo de palco, sonoplastas, contra regras, iluminadores, etc.

Escrever pequenos textos teatrais - com texto principal e secundário.

. Montagem e apresentação da peça para a própria turma e para mais uma turma da escola - Festival de Teatro - com divulgação e documentação. 


\section{Histórias sem fim:}

Ouvir uma contação de história com profissionais da cidade.

. Em roda de conversa solicitar que procurem um material que esteja "contando uma história": 0 teatro é uma das formas de contar histórias, mas podemos contar ou ler histórias sem fazer teatro? Podemos contar história por uma imagem? Todos os livros contam histórias?

Em roda de conversa cada aluno irá contar a história que está registrada em seu material recebido.

Roda de contação de histórias.

Conversar e ressaltar a diferença entre contar e ler uma história.

Jogos e exercícios práticos de expressão vocal.

Contação e/ou leitura de histórias pelas crianças e adolescentes em espaços da comunidade e na própria escola.

\section{A arte de fazer rir:}

Distribuir pilulas de risadas para os alunos.

Contar piadas.

Discutir e pesquisar sobre textos, músicas, filmes, livros, publicidades, espetáculos, etc., que tem a intenção de fazer rir.

Selecionar alguns dos materiais para serem analisados em grupos e compartilhados com a turma através de apresentações coletivas.

Ler e ver materiais antigos relacionados ao humor e estabelecer comparações entre o humor atual e o humor antigo.

Resgatar elementos do humor antigo e criar textos, letras de música e poesias usando esses elementos.

Resgatar a história do circo.

Ler livros cujo tema seja o circo.

Produzir, coletivamente, um livro sobre circo.

Realizar oficinas de circo e criar um espetáculo para ser apresentado à comunidade escolar.

\section{Se essa rua fosse minha:}

Que tipos de textos vemos na rua? Passeio pelos arredores da escola para fotografar e anotar os textos que estão na rua: pichações, grafitagens, placas de trânsito, out doors, panfletos, placas de estabelecimentos comerciais, cartazes, nome das ruas, etc.

Organizar os registros em cartazes.

Como reagimos a estes textos? Quais deixam a paisagem urbana mais bonita? 0 que é poluição visual? Por que existem textos na rua? 0 que seria bom que as pessoas lessem nas ruas?

Elaboração de um projeto para revitalização do muro da escola: pintura, grafitagens, pintura mural, textos, poesias, etc.

Realização de oficinas sobre os temas que serão produzidos nos muros.

Apresentação do projeto para as famílias, professores e comunidade.

Pintura do muro com a ajuda das famílias.

\section{Lendo imagens:}

Em grupos, procurar livros ou materiais que tenham imagens. 
Apreciar e conversar sobre as ilustrações dos livros e sua relação com os textos.

Apreciar livros que não tenham texto escrito, apenas imagens.

Reconhecimento e experimentação do Datashow: apreciação de uma história reproduzida em arquivo e contada, por exemplo: A Casa Sonolenta.

llustração e apresentação de uma história criada em grupo e transformada em arquivo.

Palestra com um ilustrador.

Oficina de ilustração.

\section{Com a boca no mundo:}

Pesquisa sobre a história do rádio.

Audições de programas de rádio antigos e atuais.

Análise e discussão sobre os programas antigos e atuais.

Elaboração de listas dos quadros dos programas de rádio.

Votação na escola sobre os programas e quadros de rádio mais ouvidos e apreciados.

Pesquisa e atividades sobre narração, sonoplastia e trilha sonora.

Elaboração de roteiros para programas e rádio.

Apresentação no circuito interno da escola.

\section{Jornalistas da Escola:}

Roda de conversa: se quiséssemos contar para outras escolas, bairros, etc., tudo o que estamos fazendo na escola, como poderíamos fazer? Retomar e ressignificar o trabalho com o Jornal da escola.

Ver e apreciar diversos jornais, mais antigos e atuais.

Classificar as sessões dos jornais.

Dividir a turma em equipes e cada equipe ficará responsável por uma das sessões.

A partir da atividade acima, elaborar cronograma para que, de cada turma, dois alunos por dia de atividade na sala de leitura escolham uma reportagem, tirinha, imagem, notícia, foto de jornal que achem mais interessante, recortem e plastifiquem para uma "Caixa de reportagens especiais".

Palestra com um jornalista de Caçapava.

Elaboração de um jornal bimestral.

\section{Entrevista com o autor:}

Estudo da obra e biografia de um autor caçapavense.

Produção de recriações da obra do autor, usando mesmo título, mas histórias diferentes, mesmas ilustrações, mas histórias diferentes, finais diferentes para mesma história, etc.

Pesquisa sobre o que é uma entrevista.

Elaboração de roteiro para entrevista.

Palestra com o autor.

Entrevista do autor pelos alunos.

Registro da entrevista.

\section{Do livro para a telona:}


Pesquisar a história do cinema.

Ler e pesquisar sobre livros que viraram filmes, seus autores, o contexto no qual foram escritos, etc.

Escolher um desses livros e ler coletivamente.

Assistir ao filme.

Estabelecer comparações e paralelos entre o livro e o filme (adaptação).

Criar uma história coletiva e adaptá-la para o vídeo.

Filmar a representação da história.

\section{Quadrinhos:}

Pesquisar as origens da história em quadrinhos.

Ler e pesquisar os diferentes tipos de histórias em quadrinhos.

Produzir diferentes tipos de histórias em quadrinhos.

Reproduzir as histórias confeccionadas para distribuir às bibliotecas das escolas municipais.

\section{Grandes nomes, grandes obras:}

Quais são os escritores mais famosos que vocês conhecem?

Procurar na sala de leitura livros e outros materiais cujos autores são "conhecidos".

Ler os livros e pesquisar as obras dos autores.

Quais dessas obras são mais conhecidas? Por que será que algumas obras e autores se tornam famosos?

E os autores desconhecidos? E as obras desconhecidas? Quem já leu um livro que adorou e que é de um autor pouco conhecido?

Como fazer para divulgar uma obra e um autor pouco conhecido?

Criar estratégias coletivas para divulgação de obras e autores que o grupo goste.

\section{Lá no Nordeste:}

Leitura de cordéis.

Leituras coletivas, dramatizadas e com fundo musical.

Ouvir e pesquisar músicas características do Nordeste.

Pesquisar, apreciar e produzir gravuras em diferentes materiais.

Criar cordéis.

Organizar uma "feira nordestina", com cordéis e apresentação de músicas.

\section{Quem canta seus males espanta:}

Leitura de letras e apreciação de musicas de diversos estilos.

Apreciação de clipes e shows de música (vídeo e ao vivo).

Canção coletiva das músicas.

Apresentação em grupos de músicas escolhidas.

Criação de paródias para algumas músicas escolhidas.

Composição de músicas dentro de determinados estilos.

Apresentação em grupo das músicas compostas. 
Confecção de livro e CD com as paródias e composições dos alunos.

\section{Jogo da poesia:}

Dar vários cartões a cada grupo de alunos, com diferentes poemas, sem colocar o título e o autor.

Pedir que leiam todos e os agrupem de diferentes maneiras.

Explorar as diversas classificações que aparecerem e, a partir daí, coordenar uma análise coletiva dos textos levando os alunos a pensarem sob diferentes perspectivas (tratamento das temáticas pelo autor, presença ou não de rimas, brincadeiras com o sentido ou com o som, estrutura, ritmo, etc.).

Os alunos retornam ao grupo e recebem os títulos e autores dos poemas, para que façam a correspondência.

O professor coloca à disposição uma mesa no centro da sala os livros onde estão os poemas, e os alunos deverão conferir sua resposta, encontrando-os nos livros.

\section{Sarau de poesia:}

Em continuidade ao jogo da poesia, os alunos escolhem dentre os poemas trabalhados pelo menos três que gostariam de ler ou declamar para os colegas e preparam a leitura em casa. O professor pode intervir durante as escolhas para evitar repetições. No dia do sarau, apresentam um dos três, conforme se sentirem mais a vontade na hora (ou também mais de um, se houver tempo).

\section{Quem conta um conto aumenta um pouco:}

Proposta envolvendo a família, na qual o aluno leva um conto para casa e, junto com a família, cria novos finais ou altera o final do conto, registrando-o através da escrita. Cada turma terá seu livro com final diferente "editado", e poderá leva-lo para casa e socializar a leitura com a família.

\section{Por dentro das letras:}

Buscar dentro da comunidade pessoas que desenvolvam atividades ligadas, de alguma forma, à leitura e escrita, como entregadores de jornais, jornaleiros, poetas, carteiros, etc., para que compartilhem suas experiências com o grupo e possam ter acesso a outra abordagem e perspectiva dentro da sua profissão.

Duração: No decorrer do ano letivo de 2015, 2016 e 2017.

Recursos necessários: Datashow, TV, vídeos, livros, jornais, quadrinhos, aparelho de som, sulfite, cartolinas, filmadora, máquina fotográfica...

Equipe envolvida: Equipe Discente / Equipe Docente / Coordenador Pedagógico.

\section{Etapa 4 - Monitora-Ação e Avalia-Ação}

Objetivo: Acompanhar e analisar a implantação e realização do projeto bem como avaliar seus resultados.

Impacto na aprendizagem: Desenvolvimento do comportamento leitor e escritor no aluno, que amplia seu repertório com vistas às produções escritas.

\section{Atividade 4.1 - "Ação-Reflexão-Ação"}

Descrição: haverá pela equipe gestora um acompanhamento sistemático e descritivo dos processos de implantação do projeto. Esse monitoramento objetiva garantir maior efetividade e verificar a aplicação adequada das ações e competências previstas e necessárias em relação aos resultados pretendidos. Além do monitoramento haverá a avaliação do projeto, para se conhecer em que medida estão sendo realizados os objetivos propostos e esperados, que outro objetivos eventuais estão também sendo promovidos, que fatores mais contribuem para explicar os resultados observados, que perspectivas existem para promover melhores resultados e que decisões devem ser tomadas para a maximização e reforço dos resultados obtidos e realização de outros.

Serão promovidos encontros com a equipe docente, para tratarmos dos seguintes aspectos:

$\checkmark$ Como são realizadas as ações propostas? 
$\checkmark$ Que reações provocam?

$\checkmark$ Necessitamos repensá-las?

$\checkmark$ Está sendo feito o que se propôs? No tempo e ocasião propostos?

$\checkmark$ Estão sendo despendidos os esforços e talentos necessários?

$\checkmark$ As responsabilidades para a efetivação dos resultados foram plenamente assumidas e cumpridas?

$\checkmark$ Que alterações ocorreram no decorrer da implementação do projeto e por quê?

$\checkmark \quad$ O que poderia ter sido feito diferente?

$\checkmark$ Foram promovidos os resultados propostos?

$\checkmark$ Que outros resultados obtiveram?

$\checkmark$ Que perspectivas existem para a promoção de melhores resultados?

$\checkmark$ Qual outra medida se pode tomar?

$\checkmark \quad$ que vamos replanejar?

Duração: 18 horas/aula, a cada bimestre.

Recursos necessários: Notebook/Impressora/Papel sulfite.

Equipe envolvida: Diretor de Escola/Coordenador Pedagógico/Equipe Docente.

\section{Atividade 4.2 - "Visão de mundo"}

Descrição: Será elaborado um instrumento de monitoramento das produções discentes, contendo espaço para a avaliação qualitativa pelo professor. De posse dos resultados serão elaborados gráficos por turma e por desempenho individual ao longo do processo. 0 referido instrumento será afixado em quadro mural, para ciência de toda a comunidade escolar, como também será anexado ao portfólio do aluno, registrando assim sua evolução no processo.

Duração: Os registros pelo professor ocorrerão durante todo o processo e os gráficos serão elaborados trimestralmente.

Recursos necessários: Notebook/Impressora/Papel sulfite/Pasta do aluno.

Equipe envolvida: Diretor de Escola / Coordenador Pedagógico / Equipe Docente / Analista de Suporte em Informática.

\section{Casos de sucesso}

Nome do Projeto: "Lendo e Aprendendo"

Nome da organização: EMEIEF Carolina Maria de Jesus

Local: Santo André

Período em que foi realizado: De 2007 a 2009

Breve relato do contexto anterior ao projeto: No ano de 2005 a situação da unidade escolar era desanimadora. Setenta alunos foram reprovados e $58,7 \%$ dos matriculados chegavam ao último ano do primeiro ciclo sem estarem alfabetizados. Para piorar, no fim de 2006 foi divulgado o Índice de Desenvolvimento da Educação Básica (IDEB) da escola - apenas 3,9, ante à média da rede municipal de 4,8.

Principais atividades desenvolvidas: foi estabelecida a meta de alfabetizar todos os alunos de até 8 anos de idade e melhorar a linguagem escrita dos 1,2 mil alunos com a implementação de um grande projeto de incentivo à leitura, o Programa Lendo e Aprendendo. Toda a comunidade foi envolvida: professores, funcionários, alunos e pais passaram a ter momentos diários de leitura e a escola ganhou novos espaços 
dedicados aos livros. Com o apoio da Secretaria Municipal de Educação e graças a uma parceria com a Pasta de Cultura, Esporte e Lazer, a equipe investiu na formação de professores. As atividades foram sistematizadas: diretora e coordenadora pedagógica montaram tabelas com as avaliações dos estudantes para discussão nas reuniões pedagógicas e nos conselhos de ciclo.

Resumo dos principais resultados alcançados: Em 2008 os esforços foram recompensados: os alunos de 7 e 8 anos dominavam leitura e escrita. Além disso, o IDEB de 2007 chegou a 4,9, índice superior aos 4,3, que, segundo o projetado, a escola deveria atingir em 2009.

Fonte: Site da Revista Gestão Escolar

http://gestaoescolar.abril.com.br/aprendizagem/leitura-toda-escola-448816.shtml

Consulta realizada em 13/10/2015, às $19 \mathrm{~h} 00$.

\section{Novidade trazida pelo projeto}

O Projeto "Visão de Mundo - Ler, escrever e compreender as entrelinhas do saber" inova porque rompe com uma contradição histórica da escola relativa à distância entre seu discurso e sua prática. 0 discurso da proposta pedagógica e dos professores é favorável ao desenvolvimento da capacidade e do gosto pela leitura, porém esbarra numa prática em que essa atividade tem pouco espaço efetivo e se utiliza de formas tradicionais de exploração, o que acaba por dificultar a concretização das intenções.

Além disso, o projeto não ocorrerá somente com ideias direcionadas pela equipe gestora, é um projeto que será compartilhado com a equipe durante todo o processo. Será desenvolvido um trabalho persistente, de estudo, de planejamento, de reflexão conjunta, de discussão de propostas, de práticas e de intervenções que possam colaborar para imprimir novas maneiras de trabalhar com a leitura e com a escrita na escola.

\section{Cronograma de execução}

Informamos abaixo a sequência de execução das etapas e atividades do projeto, especificando os anos e meses em que serão realizadas.

\begin{tabular}{|c|c|c|c|c|c|c|c|c|c|c|c|c|c|}
\hline \multirow{2}{*}{\multicolumn{2}{|c|}{ Atividades }} & \multicolumn{4}{|c|}{ Ano 1} & \multicolumn{4}{|c|}{ Ano 2} & \multicolumn{4}{|c|}{ Ano 3} \\
\hline & & \multirow{2}{*}{$\begin{array}{l}\text { Jan- } \\
\text { Mar }\end{array}$} & $\begin{array}{l}\text { Abr- } \\
\text { Jun }\end{array}$ & $\begin{array}{l}\text { Jul- } \\
\text { Set }\end{array}$ & $\begin{array}{l}\text { Out- } \\
\text { Dez }\end{array}$ & $\begin{array}{l}\text { Jan- } \\
\text { Mar }\end{array}$ & $\begin{array}{l}\text { Abr- } \\
\text { Jun }\end{array}$ & $\begin{array}{l}\text { Jul- } \\
\text { Set }\end{array}$ & $\begin{array}{l}\text { Out- } \\
\text { Dez }\end{array}$ & $\begin{array}{l}\text { Jan- } \\
\text { Mar }\end{array}$ & \multirow{2}{*}{$\begin{array}{l}\text { Abr- } \\
\text { Jun }\end{array}$} & \multirow{2}{*}{$\begin{array}{l}\text { Jul- } \\
\text { Set }\end{array}$} & $\begin{array}{l}\text { Out- } \\
\text { Dez }\end{array}$ \\
\hline \multirow{3}{*}{ Etapa 1} & Ativ. 1.1 & & & & & & & & & & & & \\
\hline & Ativ. 1.2 & & & & & & & & & & & & \\
\hline & Ativ. 1.3 & & & & & & & & & & & & \\
\hline \multirow{3}{*}{ Etapa 2} & Ativ. 2.1 & & & & & & & & & & & & \\
\hline & Ativ. 2.2 & & & & & & & & & & & & \\
\hline & Ativ. 2.2 & & & & & & & & & & & & \\
\hline Etapa 3 & Ativ. 3.1 & & & & & & & & & & & & \\
\hline \multirow{2}{*}{ Etapa 4} & Ativ. 4.1 & & & & & & & & & & & & \\
\hline & Ativ. 4.2 & & & & & & & & & & & & \\
\hline
\end{tabular}




\section{Gestão Estratégica}

Relacionamos a seguir os objetivos estratégicos, metas, indicadores e acompanhamento do projeto, relacionados à decisão estratégica de implantar um projeto de leitura.

\begin{tabular}{|c|c|c|c|}
\hline Objetivos & Metas & Indicadores & Acompanhamento \\
\hline \multirow{2}{*}{$\begin{array}{l}\text { Aumentar o } \\
\text { nível de } \\
\text { compreensão } \\
\text { dos alunos } \\
\text { em Língua } \\
\text { Portuguesa e } \\
\text { Redação }\end{array}$} & $\begin{array}{l}\text { Aumentar o número de } \\
\text { aprovações nas respectivas } \\
\text { disciplinas e reduzir o índice } \\
\text { dos alunos promovidos pelo } \\
\text { Conselho de Classe em } \\
20 \% \text { ao final do primeiro ano } \\
\text { de projeto; } 30 \% \text { no segundo } \\
\text { ano e } 40 \% \text { no terceiro, em } \\
\text { relação à situação inicial. }\end{array}$ & $\begin{array}{l}\text { Médias das disciplinas } \\
\text { e relatórios de turmas. } \\
\text { Número de alunos } \\
\text { aprovados }\end{array}$ & $\begin{array}{l}\text { Controle trimestral do } \\
\text { rendimento das turmas e } \\
\text { definição de ações } \\
\text { corretivas para o } \\
\text { planejamento, levando } \\
\text { em consideração } \\
\text { também o feedback de } \\
\text { alunos e professores. }\end{array}$ \\
\hline & $\begin{array}{l}\text { Zerar o índice de aluno nos } \\
\text { níveis abaixo do básico e } \\
\text { básico na avaliação externa } \\
\text { SARESP, para Língua } \\
\text { Portuguesa, e elevar em } \\
30 \% \text { o índice no nível } \\
\text { avançado, em relação à } \\
\text { situação inicial, até o final do } \\
\text { projeto. }\end{array}$ & $\begin{array}{l}\text { Média da avaliação } \\
\text { externa SARESP para } \\
\text { o ano de } 2017 . \\
\text { Distribuição percentual } \\
\text { dos alunos nos níveis } \\
\text { de proficiência na } \\
\text { avaliação externa } \\
\text { SARESP } 2017 .\end{array}$ & $\begin{array}{l}\text { Análise trimestral de } \\
\text { habilidades necessárias, } \\
\text { como seu } \\
\text { aprofundamento. } \\
\text { Discussão e } \\
\text { estabelecimento de } \\
\text { ações específicas com } \\
\text { base nas avaliações } \\
\text { anuais e nos simulados. }\end{array}$ \\
\hline $\begin{array}{l}\text { Melhorar a } \\
\text { qualidade do } \\
\text { ensino } \\
\text { através da } \\
\text { formação } \\
\text { continuada } \\
\text { em serviço }\end{array}$ & $\begin{array}{l}\text { Desenvolver um plano anual } \\
\text { de capacitação para o } \\
\text { trabalho com a leitura para } \\
100 \% \text { dos professores até o } \\
\text { final do primeiro ano do } \\
\text { projeto. }\end{array}$ & $\begin{array}{l}\text { Percentual de } \\
\text { professores } \\
\text { capacitados. }\end{array}$ & $\begin{array}{l}\text { Análise mensal das } \\
\text { atividades propostas } \\
\text { pelos professores } \\
\text { capacitados. }\end{array}$ \\
\hline $\begin{array}{l}\text { Ampliar o } \\
\text { acervo de } \\
\text { livros. }\end{array}$ & $\begin{array}{l}\text { Ampliar em } 100 \% \text { o acervo } \\
\text { de livros, em relação à } \\
\text { situação inicial, até o fim do } \\
\text { primeiro ano do projeto. }\end{array}$ & $\begin{array}{l}\text { Número de livros do } \\
\text { acervo. }\end{array}$ & $\begin{array}{l}\text { Análise semanal do } \\
\text { recebimento de livros. }\end{array}$ \\
\hline $\begin{array}{l}\text { Estimular nos } \\
\text { alunos o } \\
\text { gosto pela } \\
\text { leitura } \\
\text { permanente. }\end{array}$ & $\begin{array}{l}\text { Aumentar o número de } \\
\text { busca por livros na sala de } \\
\text { leitura (empréstimos) em } \\
40 \% \text { no final do primeiro ano } \\
\text { de projeto; } 60 \% \text { no segundo } \\
\text { ano e } 80 \% \text { no terceiro, em } \\
\text { relação à situação inicial. }\end{array}$ & $\begin{array}{l}\text { Número de busca por } \\
\text { livros na sala de leitura } \\
\text { (empréstimos) no final } \\
\text { do primeiro ano, no } \\
\text { final segundo e no final } \\
\text { do terceiro ano. }\end{array}$ & $\begin{array}{l}\text { Reuniões quinzenais } \\
\text { com o professor auxiliar } \\
\text { de docente e com o } \\
\text { professor de Língua } \\
\text { Portuguesa. } \\
\text { Incrementar atividades e } \\
\text { tarefas que envolvam } \\
\text { pesquisas e leitura de } \\
\text { livros. }\end{array}$ \\
\hline
\end{tabular}




\section{Continuidade do projeto}

O projeto "Visão de Mundo - Ler, escrever e compreender as entrelinhas do saber" propicia adentrar no universo da literatura através de diversas modalidades de leitura sendo colocadas simultaneamente em prática. Após o desenvolvimento desse trabalho não se sai igual aluno, nem professor, nem comunidade. Saem todos melhores, mais letrados, mais participativos, mais sensíveis, mais críticos e mais confiantes de suas capacidades.

A continuidade do projeto estará relacionada aos resultados alcançados e ao envolvimento do público alvo. Podemos, no entanto, afirmar que toda essa mudança positiva no que se refere ao ato de ler na rotina da escola e das famílias será mantida, aprofundada e incentivada ainda mais nos anos que se seguirem ao projeto, pois, uma vez desenvolvido o comportamento leitor, 0 ato de ler se torna um ato de prazer, de conhecer e de compreender as entrelinhas do mundo do saber. Isso desenvolvido, não há retrocesso.

\section{Marketing e Comunicação}

Seguem, na sequência, os meios de transmissão do projeto e os canais para disseminação da comunicação.

São explicitados ainda os parceiros estratégicos e como se dará a divulgação de resultados.

\section{Lançamento do projeto}

O lançamento oficial do projeto ocorrerá no último dia da semana de capacitação docente, no período da tarde, onde através da integração escola e comunidade estarão presentes alunos, professores, funcionários e pais ou responsáveis. 0 prédio escolar, que estará todo decorado com cartazes motivacionais, letras de música, telas e poesias desde o primeiro dia de capacitação docente, será o palco do evento.

Haverá a abertura pelo Diretor da Escola, que através de uma exposição audiovisual buscará sensibilizar e mobilizar os presentes para a plena participação nas atividades. Esclarecerá sobre a importância do projeto, explicando em seguida sobre suas etapas. Em continuidade haverá a apresentação de uma peça teatral "Memórias da Emília" - pela equipe do Sítio do Pica Pau Amarelo. A estratégia utilizada para atrair o maior número de participantes será o envio de um convite nominal a cada pai ou responsável, constando a abertura do projeto e a apresentação teatral.

\section{Canais de comunicação e acompanhamento do projeto}

\section{Marketing interno}

Visando ao encantamento das equipes pedagógica e administrativa com as ações propostas, a criar um ambiente no qual todos trabalhem com 0 mesmo foco, e, a valorizar e capacitar às habilidades dos colaboradores, desenvolveremos o projeto internamente utilizando os seguintes canais:

$\checkmark$ Clube de leitura: será implantado em grupos pequenos, por meia hora semanal, às segundas-feiras, ao início do período. No primeiro encontro cada funcionário levará sua leitura favorita e irá declarar aos demais o motivo do encantamento por aquele texto. Após todos expuserem suas preferências será realizada uma votação e o livro escolhido será lido pelo grupo nesses encontros semanais. Ao término do primeiro livro haverá a votação por outro, e assim sucessivamente. Consideramos a importância do clube de leitura como ferramenta de criação de laços efetivos e trocas de conhecimentos e experiências, que em muito contribuem para a construção da cultura escolar.

$\checkmark \quad$ Treinamentos: semestralmente, em parceria com a Supervisão de Bibliotecas da Rede Escolar SESI-S serão promovidas palestras aos docentes referentes à formação do sujeito leitor.

$\checkmark$ Cartazes: quinzenalmente serão dispostos nas salas dos professores cartazes alusivos ao projeto, com sugestões e mensagens que motivem à equipe a buscar melhores resultados de aprendizagem dos alunos. 


\section{Marketing externo}

Para a comunicação com os clientes/usuários serão utilizados os seguintes canais de comunicação:

$\checkmark$ Cartazes: quinzenalmente serão dispostos no pátio escolar e no mural informativo, à entrada do prédio escolar, cartazes alusivos ao projeto, com sugestões e mensagens que motivem às equipes discentes $e$ familiares o desenvolvimento da competência leitora e escritora.

$\checkmark$ Revista eletrônica: trimestralmente será encaminhada ao e-mail dos clientes/usuários uma revista eletrônica, confeccionada pelos alunos e revisada pelo professor de Língua Portuguesa, contendo as atividades desenvolvidas, depoimentos de alunos, professores e pais, número de livros emprestados e dicas de leitura.

$\checkmark$ Pesquisa de marketing: ao final de cada ano será encaminhada ao e-mail dos clientes/usuários uma pesquisa de satisfação, a fim de verificarmos o índice de satisfação dos mesmos em relação às ações realizadas, ao acervo e levantarmos sugestões de melhorias.

\section{Parceiros estratégicos}

Será de extrema importância para o desenvolvimento do projeto o estabelecimento de parcerias, as quais seguem relacionadas:

1. Diretoria de Educação e Cultura do SESI-SP - Parceria interna.

Através do programa Literatura Viva, que promove o encontro entre os protagonistas da leitura - autor e leitor - por meio de ações diferenciadas, lúdicas e criativas, será disponibilizada a presença de autores renomados, e os alunos terão a oportunidade de ampliarem a visão de mundo, conhecendo e interagindo com novos escritores, além dos caçapavenses.

Ainda nesta parceria, dentro do programa de Literatura e Cultura Itinerante, que objetiva levar literatura, arte e cultura a milhares de pessoas, os alunos poderão ter acesso, na própria escola a ilustradores e a espetáculos de danças e peças teatrais, com grupos renomados.

Em contrapartida, a escola oferecerá ao parceiro a oportunidade do desenvolvimento de sua atividade fim ao público alvo e a divulgação dos serviços de cultura da casa.

Para o estabelecimento desta parceria será encaminhado ofício ao setor competente.

\section{Editora SESI-SP e Supervisão de Bibliotecas/SESI-SP - Parceria Interna}

Colaboração da Supervisora de Bibliotecas, bem como da Editora, em relação aos títulos para a ampliação do acervo de livros da unidade escolar.

Em contrapartida, a escola oferecerá à Supervisão de Bibliotecas a oportunidade do desenvolvimento de sua atividade fim ao público alvo e, à Editora, a oportunidade de divulgar seus produtos.

Para o estabelecimento desta parceria será encaminhado ofício ao setor competente.

3. Prefeitura Municipal de Caçapava - Órgão Público

Esta parceria propiciará a presença de um contador de histórias e de um jornalista do município às propostas desenvolvidas.

Em contrapartida, a escola oferecerá ao parceiro a oportunidade do desenvolvimento de sua atividade fim ao público alvo, bem como haverá divulgação do jornal municipal e dos serviços culturais do município.

Para o estabelecimento desta parceria será encaminhado ofício ao setor competente.

4. Sitio do Pica Pau Amarelo - Órgão Público

Esta parceria propiciará aos alunos assistirem a apresentação de uma peça teatral com os personagens do Sítio na própria escola, como também participarem de uma palestra referente à criação de peças teatrais. 
Em contrapartida, a escola oferecerá ao parceiro a oportunidade do desenvolvimento de sua atividade educativa e cultural na cidade de Caçapava, divulgando assim vida e obra de Monteiro Lobato e o serviço oferecido pelo Sítio do Pica Pau Amarelo, antiga residência de Monteiro Lobato, na cidade de Taubaté.

Para o estabelecimento desta parceria será encaminhado ofício ao setor competente.

\section{Divulgação de resultados}

Os resultados parciais do projeto, discutidos nas reuniões bimestrais com a equipe docente, bem como os gráficos elaborados trimestralmente, serão consolidados em um único relatório, ao término do ano letivo. Esses dados servirão de base para a elaboração de uma apresentação audiovisual, que será trabalhada com a equipe docente no dia da avaliação final da unidade escolar. Nesse dia também serão convidados pais e ou responsáveis para a discussão e na oportunidade ratificaremos a relevância do projeto.

\section{Equipe do Projeto}

Para a implantação e desenvolvimento do projeto contaremos com duas equipes de trabalho: a interna e a externa.

\section{Equipe interna}

Estão relacionados no quadro abaixo os componentes da equipe interna:

\begin{tabular}{|c|c|c|c|c|}
\hline Cargo & Formação & $\begin{array}{c}\text { Tempo na } \\
\text { escola }\end{array}$ & $\begin{array}{c}\text { Experiência } \\
\text { anterior }\end{array}$ & $\begin{array}{c}\text { Responsável pelas } \\
\text { atividades }\end{array}$ \\
\hline Diretor Escolar & Pedagogia & 16 anos & Magistério & $\begin{array}{r}\text { Atividade 1.1 } \\
\text { Atividade 1.3 } \\
\text { Atividade 2.2 } \\
\text { Atividade 4.1 }\end{array}$ \\
\hline $\begin{array}{c}\text { Coordenador } \\
\text { Pedagógico }\end{array}$ & Pedagogia & 7 anos & Magistério & $\begin{array}{r}\text { Atividade 1.1 } \\
\text { Atividade 1.2 } \\
\text { Atividade 2.3 } \\
\text { Atividade 4.1 }\end{array}$ \\
\hline $\begin{array}{c}\text { Professor Auxiliar de } \\
\text { Docente }\end{array}$ & Pedagogia & 27 anos & Magistério & Atividade 2.1 \\
\hline $\begin{array}{c}\text { Professor de Língua } \\
\text { Portuguesa }\end{array}$ & Letras & 9 anos & Magistério & $\begin{array}{r}\text { Atividade 1.2 } \\
\text { Atividade 3.1 }\end{array}$ \\
\hline $\begin{array}{c}\text { Analista de Suporte } \\
\text { em Informática }\end{array}$ & Matemática & 4 anos & Magistério & Atividade 4.2 \\
\hline
\end{tabular}

\section{Profissionais externos}

Como profissionais externos, contaremos com as seguintes categorias de profissionais:

\begin{tabular}{|c|c|c|}
\hline Tipo de profissional & Competências necessárias & Participação no projeto \\
\hline Contador de história & Pedagogia & Contação de histórias \\
\hline Jornalista & Jornalismo & Palestra \\
\hline
\end{tabular}


Visão de Mundo: ler, escrever e compreender as entrelinhas do saber

\begin{tabular}{|c|c|c|}
\hline llustrador & Cursos específicos na área & Oficina de ilustração \\
\hline Escritor & Cursos específicos na área & $\begin{array}{c}\text { Palestra/Apresentação de } \\
\text { obras literárias }\end{array}$ \\
\hline Atores teatrais & Cursos específicos na área & Apresentação teatral \\
\hline Bailarinos & Cursos específicos na área & Apresentação de dança \\
\hline
\end{tabular}

\section{Plano financeiro}

Para a implementação do projeto haverá necessidade de um investimento no valor de $R \$ 86.880,35$, solicitado através do Edital, com contrapartida da escola no valor de $\mathrm{R} \$ 18.626,36$, conforme discriminado nos quadros a seguir.

\section{Investimentos (despesas de capital)}

São registrados primeiramente os investimentos (despesas de capital) referentes às obras, infraestrutura e material permanente:

\begin{tabular}{|c|c|c|c|}
\hline Obras e infraestrutura & Ano 1 & Ano 2 & Ano 3 \\
\hline Reforma da Sala de Leitura & $5.000,00$ & 0,00 & 0,00 \\
\hline Total & $\mathbf{5 . 0 0 0 , 0 0}$ & $\mathbf{0 , 0 0}$ & $\mathbf{0 , 0 0}$ \\
\hline
\end{tabular}

\begin{tabular}{|c|c|c|c|}
\hline Material permanente & Ano 1 & Ano 2 & Ano 3 \\
\hline Microcomputador & $4.000,00$ & 0,00 & 0,00 \\
\hline Mesas & $1.000,00$ & & \\
\hline Cadeiras & $3.000,00$ & & \\
\hline Estantes & $2.000,00$ & & \\
\hline Livros paradidáticos & $5.000,00$ & $3.000,00$ & $3.000,00$ \\
\hline Total & $15.000,00$ & $3.000,00$ & $3.000,00$ \\
\hline
\end{tabular}

\section{Despesas correntes}

$\mathrm{Na}$ sequência encontram-se discriminadas as despesas correntes, referentes aos materiais de consumo, gastos com locomoção e serviços de terceiros:

\begin{tabular}{|c|c|c|c|}
\hline Material de consumo & Ano 1 & Ano 2 & Ano 3 \\
\hline Material de divulgação - panfletos & 500,00 & 550,00 & 600,00 \\
\hline Cartazes & 400,00 & 450,00 & 500,00 \\
\hline Cartuchos & 500,00 & 550,00 & 600,00 \\
\hline Folders & 400,00 & 450,00 & 500,00 \\
\hline Total & $1.800,00$ & $2.000,00$ & $2.200,00$ \\
\hline
\end{tabular}


Vera Lúcia Ávila Torres Naliato

\begin{tabular}{|c|c|c|c|}
\hline Gastos com locomoção & Ano 1 & Ano 2 & Ano 3 \\
\hline Locomoção com carro de passeio & $2.000,00$ & $2.200,00$ & $2.400,00$ \\
\hline Locomoção com ônibus & $3.000,00$ & $3.300,00$ & $3.600,00$ \\
\hline Locomoção com Van & $1.500,00$ & $1.600,00$ & $1.700,00$ \\
\hline Total & $\mathbf{6 . 5 0 0 , 0 0}$ & $7.100,00$ & $7.700,00$ \\
\hline
\end{tabular}

\begin{tabular}{|c|c|c|c|}
\hline Serviços de terceiros & Ano 1 & Ano 2 & Ano 3 \\
\hline Contador de Histórias & 400,00 & 450,00 & 500,00 \\
\hline Atores Teatrais & $2.000,00$ & $2.200,00$ & $2.400,00$ \\
\hline Escritor & 600,00 & 700,00 & 800,00 \\
\hline Jornalista & 400,00 & 450,00 & 500,00 \\
\hline Ilustrador & 400,00 & 450,00 & 500,00 \\
\hline Bailarinos & $2.000,00$ & $2.200,00$ & $2.400,00$ \\
\hline Total & $\mathbf{5 . 8 0 0 , 0 0}$ & $\mathbf{6 . 4 5 0 , 0 0}$ & $\mathbf{7 . 1 0 0 , 0 0}$ \\
\hline
\end{tabular}

\section{Outros gastos}

No quadro abaixo foram lançados os gastos adicionais, que se referem à despesa de pessoal.

\begin{tabular}{|c|c|c|c|}
\hline Gastos adicionais & Ano 1 & Ano 2 & Ano 3 \\
\hline $\begin{array}{l}\text { Despesa de pessoal (hora extra para } \\
\text { professor) }\end{array}$ & $4.299,20$ & $4.729,12$ & $5.202,03$ \\
\hline Total & $4.299,20$ & $4.729,12$ & $5.202,03$ \\
\hline
\end{tabular}

\section{Recursos totais}

Todos os itens supracitados são lançados no quadro a seguir, fornecendo assim uma visão geral dos recursos necessários:

\begin{tabular}{|c|c|c|c|c|}
\hline Tipo de item & Ano 1 & Ano 2 & Ano 3 & Total \\
\hline Despesas de Capital & $\mathbf{2 0 . 0 0 0 , 0 0}$ & $\mathbf{3 . 0 0 0 , 0 0}$ & $\mathbf{3 . 0 0 0 , 0 0}$ & $\mathbf{2 6 . 0 0 0 , 0 0}$ \\
\hline Obras e infraestrutura & $5.000,00$ & & & \\
\hline Material permanente & $15.000,00$ & $3.000,00$ & $3.000,00$ & \\
\hline Despesas Correntes & $14.100,00$ & $15.550,00$ & $17.000,00$ & $46.650,00$ \\
\hline Material de consumo & $1.800,00$ & $2.000,00$ & $2.200,00$ & \\
\hline Gastos com locomoção & $6.500,00$ & $7.100,00$ & $7.700,00$ & \\
\hline Serviços de terceiros & $5.800,00$ & $6.450,00$ & $7.100,00$ & \\
\hline Total de recursos do edital & $34.100,00$ & $18.550,00$ & $\mathbf{2 0 . 0 0 0 , 0 0}$ & $\mathbf{7 2 . 6 5 0 , 0 0}$ \\
\hline Gastos adicionais & $4.299,20$ & $4.729,12$ & $5.202,03$ & $14.230,35$ \\
\hline Recursos totais & $38.399,20$ & $23.279,12$ & $25.202,03$ & $\mathbf{8 6 . 8 8 0 , 3 5}$ \\
\hline
\end{tabular}

Categoria em que o projeto se enquadra: o projeto se enquadra na Categoria $\mathrm{D}$ do edital. 


\section{Fontes de recursos}

Não há fonte extra de recursos. Os recursos são os disponibilizados pelo edital.

\section{Contrapartida}

Como contrapartida, a escola participa com o valor total de $\mathrm{R} \$ 18.626,36$, que está discriminado a seguir, relacionando o número de horas dedicadas ao projeto pelos respectivos profissionais e o valor médio/hora.

\begin{tabular}{|l|c|c|c|}
\hline \multicolumn{1}{|c|}{ Profissionais } & $\begin{array}{c}\text { Horas dedicadas } \\
\text { ao projeto }\end{array}$ & Valor médio/hora & $\begin{array}{c}\text { Contrapartida por } \\
\text { profissional }\end{array}$ \\
\hline Diretor de Escola & 60 & 82,00 & $4.920,00$ \\
\hline $\begin{array}{l}\text { Coordenador } \\
\text { Pedagógico }\end{array}$ & 90 & 70,00 & $6.300,00$ \\
\hline $\begin{array}{l}\text { Professor de Língua } \\
\text { Portuguesa }\end{array}$ & 120 & 26,87 & $3.224,40$ \\
\hline Professor de Arte & 24 & 26,87 & 644,88 \\
\hline $\begin{array}{l}\text { Professor de } \\
\text { Educação Física }\end{array}$ & 24 & 26.87 & 644,88 \\
\hline $\begin{array}{l}\text { Professor Auxiliar de } \\
\text { Docente }\end{array}$ & 60 & 26,87 & $1.612,20$ \\
\hline $\begin{array}{l}\text { Analista de Suporte } \\
\text { em Informática }\end{array}$ & 40 & 32,00 & $1.280,00$ \\
\hline $\begin{array}{c}\text { Total de } \\
\text { contrapartida }\end{array}$ & 418 & - & $18.626,36$ \\
\hline
\end{tabular}

Diante do plano apresentado concluímos que o projeto atende às exigências do edital, viabilizando assim sua implantação.

A partir desse dispêndio e das atividades desenvolvidas esperamos elevar o nível de proficiência dos alunos em Língua Portuguesa, atingindo os objetivos estratégicos e metas, já explicitados no quadro de gestão estratégica.

\section{Referências}

ABRAMOVICH, Fanny. Literatura Infantil: Gostosuras e bobices. 5ª Ed. São Paulo: Scipione, 1997.

BALDI, Elizabeth. Leitura nas séries iniciais: uma proposta para formação de leitores de literatura. Porto Alegre: Projeto, 2009.

LAJOLO, Marisa. Do mundo da leitura para a leitura do mundo. 6ª Ed. São Paulo: Ática, 2002.

LERNER, Delia. Ler e escrever na escola: o real, o possível e o necessário. Porto Alegre: Artmed, 2002.

LUCK, Heloisa. Dimensões da gestão escolar e suas competências. Curitiba: Positivo, 2009.

SOLÉ, Isabel. Estratégias de leitura. Trad. Claudia Schilling, 6ª Ed. Porto Alegre: Artmed, 1998. 